\title{
Nutritional aspects and possible pathological mechanisms of hyperhomocysteinaemia: an independent risk factor for vascular disease
}

\author{
Michelle C. McKinley \\ Northern Ireland Centre for Diet and Health, University of Ulster, Coleraine BT52 1SA, UK
}

\begin{abstract}
Numerous case-control and prospective studies have identified elevated plasma homocysteine as a strong independent risk factor for cerebovascular, cardiovascular and peripheral vascular disease. Homocysteine is formed as a result of the breakdown of the dietary amino acid methionine. Once formed, homocysteine is either remethylated to methionine, or undergoes a trans-sulfuration reaction to form cysteine. The re-methylation of homocysteine to methionine is dependent on three $\mathrm{B}$-vitamins, i.e. riboflavin, vitamin $\mathrm{B}_{12}$ and folate. The second pathway of homocysteine metabolism is the trans-sulfuration pathway which requires both vitamin $\mathrm{B}_{6}$ and riboflavin for its activity. Thus, up to four B-vitamins are required for intracellular homocysteine metabolism. Many studies have noted strong inverse relationships between homocysteine levels and the status of both vitamin $\mathrm{B}_{12}$ and folate. However, the relationship between vitamin $\mathrm{B}_{6}$ status and homocysteine is still uncertain. Similarly, numerous intervention studies have demonstrated effective lowering of homocysteine levels as a result of folate and vitamin $\mathrm{B}_{12}$ supplementation, while the homocysteine-lowering ability of vitamin $\mathrm{B}_{6}$ is unclear. Even though riboflavin plays a crucial role in both the trans-sulfuration and remethylation pathways of homocysteine metabolism, the relationship between riboflavin status and homocysteine levels has not been investigated. The exact mechanism that explains the vascular toxicity of elevated homocysteine levels is unknown at present, studies indicate that it is both atherogenic and thrombogenic. To date, no randomized clinical trial has demonstrated that lowering of homocysteine levels is beneficial in terms of reducing the prevalence of vascular disease. It is probable, however, that optimal B-vitamin status is important in the prevention of vascular disease.
\end{abstract}

Homocysteine: Vascular disease: Vitamin B

\section{Historical perspective and metabolism}

Homocysteine was first discovered in 1932 as a breakdown product of methionine (Du Vigneaud, 1952). Another important milestone in homocysteine's history occurred in Northern Ireland when Carson \& Neill (1962) first described the inborn error of methionine metabolism called homocystinuria. Almost simultaneously Gerritsen \& Waisman (1964), in the USA, identified homocysteine in the urine of an infant who failed to thrive. After these initial reports, numerous studies began to investigate the biochemical basis and clinical features associated with homocystinuria. Mudd et al. (1964) reported that homocystinuria was caused by a lack of the trans-sulfuration enzyme cystathionine $\beta$-synthase in the liver and brain. Since this discovery, other rare enzyme defects that also cause homocystinuria have been identified (Fenton \&
Rosenberg, 1995; Rosenblatt, 1995), and these defects are discussed later in the present review (p. 225).

Once formed, homocysteine is either remethylated to methionine or undergoes a trans-sulfuration reaction to form cysteine. The remethylation pathway involves two critical enzymes. The first enzyme is methionine synthase, which catalyses the remethylation of homocysteine to methionine, and requires vitamin $B_{12}$ in the form of methylcobalamin as cofactor and folate in the form of 5-methyltetrahydrofolate as co-substrate (Finkelstein, 1990). The second critical enzyme in the remethylation pathway is methylenetetrahydrofolate reductase (MTHFR). This enzyme is responsible for the conversion of 5,10-methylenetetrahydrofolate to 5-methyltetrahydrofolate, which then acts as co-substrate for the vitamin $\mathrm{B}_{12}$-dependent remethylation of homocysteine to methionine. Riboflavin in the form of FAD is required as a prosthetic group for MTHFR (Bates \&

Abbreviation: MTHFR, methylenetetrahydrofolate reductase.

Corresponding author: Dr Michelle McKinley, fax +44(0)1265 324965, email MC.McKinley@ulst.ac.uk 
Fuller, 1986). During trans-sulfuration homocysteine is irreversibly condensed with serine to form cystathionine. This reaction is catalysed by cystathionine $\beta$-synthase, which is pyridoxal 5'-phosphate (vitamin $\mathrm{B}_{6}$ )-dependent (Mudd et al. 1995). Pyridoxal 5'-phosphate, the active coenzyme form of vitamin $\mathrm{B}_{6}$, is formed through pyridoxine oxidation by the FMN-dependent enzyme, pyridoxine phosphate oxidase (McCormick, 1989). Thus, riboflavin is actually required for the activity of both pathways of homocysteine metabolism. S-adenosyl methionine, the breakdown product of methionine, controls the flux of homocysteine through the trans-sulfuration and remethylation pathways (Finkelstein, 1990). High levels of S-adenosyl methionine inhibit the remethylation enzyme MTHFR and activate the trans-sulfuration pathway; alternatively, low levels of S-adenosyl methionine activate the remethylation pathway and inhibit activity of the transsulfuration enzyme, cystathionine $\beta$-synthase (Selhub \& Miller, 1992).

\section{Epidemiological evidence for elevated homocysteine as a risk factor for vascular disease}

\section{Retrospective case-control and cross-sectional studies}

Kilmer McCully (1969) proposed that the high prevalence of premature vascular disease and thromboembolic events observed among patients with homocystinuria occurred as a direct result of the high homocysteine levels associated with the condition. Since this initial hypothesis, numerous casecontrol and cross-sectional studies have investigated the relationship between elevated homocysteine levels and vascular disease. There are now approximately seventy published case-control studies. Boushey et al. (1995) carried out a meta-analysis of available case-control, cross-sectional and prospective studies. Five cross-sectional and nineteen case-control studies were included in this meta-analysis, and the main conclusion was that elevations in homocysteine levels were considered an independent risk factor for arteriosclerotic vascular disease; the odds ratio for a $5 \mu \mathrm{mol} / 1$ increase in homocysteine was calculated to be 1.6 for men and 1.8 for women. Case-control studies have found elevated homocysteine levels in patients with CHD (Kang et al. 1986a; Dalery et al. 1995; Hopkins et al. 1995; Robinson et al. 1995; Aronow \& Ahn, 1997; Yoo et al. 1999), stroke (Brattstrom et al. 1984, 1992b; Lindgren et al. 1995; Markus et al. 1997), peripheral vascular disease (Malinow et al. 1989; Aronow \& Ahn, 1998), myocardial infarction (Malinow et al. 1996) and venous thromboembolism (den Heijer et al. 1996; Simioni et al. 1996; Eichinger et al. 1998) compared with matched controls. For example, a study by Clarke et al. (1991) found hyperhomocysteinaemia in $42 \%$ of patients with cerebrovascular disease, in $28 \%$ of patients with peripheral vascular disease and in $30 \%$ of patients with coronary artery disease, but no hyperhomocysteinaemia in the controls. Results from the European Concerted Action Project (Graham et al. 1997), a large multi-centred case-control study involving 750 cases of atherosclerotic vascular disease and 800 controls, demonstrated that an elevated plasma homocysteine level was an independent risk factor for vascular disease, and that the effect was graded. The relative risk for vascular disease for the top $20 \%$ compared with the bottom $80 \%$ of the control homocysteine distribution was $2 \cdot 2$. Cross-sectional and case-control studies have also demonstrated a significant association between homocysteine levels and the extent of vascular disease in the coronary (Montalescot et al. 1997; Verhoef et al. 1997b), carotid (Malinow et al. 1993; Selhub et al. 1995; Aronow \& Ahn, 1997; Bots et al. 1997), aortic (Konecky et al. 1997) and peripheral (van den Berg et al. 1996) arteries. Taylor et al. (1991) studied a cohort of 214 patients with symptomatic lower-extremity arterial occlusive disease and/or symptomatic cerebral vascular disease. They found that clinical progression of lower extremity and coronary disease, but not cerebrovascular disease, was more likely in patients with elevated plasma homocysteine levels than in patients with normal levels. Also, the rate of disease progression was more rapid among individuals with elevated homocysteine levels. Recently, Voutilainen et al. (1998) studied 513 healthy men and women aged 45-69 years with no clinical cardiovascular disease, and found elevated plasma homocysteine concentrations in men were associated with early atherosclerosis, as demonstrated by increased wall thickness of the common carotid artery, but found no such association in women.

\section{Prospective studies}

Although the number of case-control studies that show a relationship between hyperhomocysteinaemia and vascular disease is quite overwhelming at this stage, this type of study does not demonstrate a causal relationship. Prospective studies, on the other hand, provide stronger support for a causal relationship. There are currently twentyfour prospective studies investigating the relationship between homocysteine levels and vascular disease. These studies can be divided into two types, prospective nested case-control studies and prospective cohort studies, summarized in Tables 1 and 2 respectively. To date, prospective studies have demonstrated that homocysteine is an independent risk factor for myocardial infarction (Stampfer et al. 1992; Stehouwer et al. 1998; Bots et al. 1999; Ridker et al. 1999), CHD (Arnesen et al. 1994; Moustapha et al. 1998; Taylor et al. 1999), stroke (Perry et al. 1995; Petri et al. 1996; Bostom et al. 1997b, 1999; Stehouwer et al. 1998; Bots et al. 1999; Ridker et al. 1999), venous thromboembolism (Ridker et al. 1997; Shemin et al. 1999), IHD (Wald et al. 1998) and all-cause mortality (Nygard et al. 1997a; Kark et al. 1999), even after adjustment for confounders such as other vascular risk factors.

The relationship appears to be graded, i.e. it is seen across the range of homocysteine value, with no obvious threshold associated with increased risk (Arnesen et al. 1994; Perry et al. 1995; Nygard et al. 1997a). Results from the prospective studies however are inconsistent. Among the nested case-control studies, six studies have been negative and seven studies have been positive. Five of the thirteen nested case-control studies were carried out in the US Physician cohort, and only two studies found a positive association between elevated homocysteine levels and vascular disease. However, the US Physician cohort 
Table 1. Results from prospective nested case-control studies of homocysteine (Hcy) and vascular disease of individuals without disease at study entry

(Values for odds ratio $(\mathrm{OR})$ and relative risk (RR) are given with $95 \% \mathrm{Cl}$ in parentheses)

\begin{tabular}{|c|c|c|c|c|c|c|c|c|c|}
\hline \multirow[b]{2}{*}{ Study, country, follow-up } & \multirow{2}{*}{$\begin{array}{l}\text { Percent- } \\
\text { age of } \\
\text { males }\end{array}$} & \multirow{2}{*}{ Cases } & \multirow[b]{2}{*}{ Controls } & \multirow{2}{*}{$\begin{array}{l}\text { Age (years), } \\
\text { type of group }\end{array}$} & \multirow{2}{*}{ End point } & \multicolumn{2}{|c|}{ Hcy $(\mu \mathrm{mol} / \mathrm{l})$} & \multirow[b]{2}{*}{ OR or RR $\dagger$} & \multirow{2}{*}{$\begin{array}{l}\text { Hcy } \\
\text { identified as } \\
\text { a risk } \\
\text { factor? }\end{array}$} \\
\hline & & & & & & Cases & Control & & \\
\hline $\begin{array}{l}\text { Stampfer et al. (1992) } \\
\text { USA, } 5 \text { years }\end{array}$ & 100 & 271 & 271 & $\begin{array}{l}\text { 40-84 US } \\
\text { physicians }\end{array}$ & MI or CHD death & $11 \cdot 1$ & $10 \cdot 5^{\star}$ & $\begin{array}{r}\mathrm{RR} \text { of } \mathrm{MI} 3 \cdot 4 \\
(1.3,8 \cdot 8) \ddagger\end{array}$ & Yes \\
\hline $\begin{array}{l}\text { Alfthan et al. (1994) } \\
\text { Finland, } 9 \text { years }\end{array}$ & 51 & 265 & 269 & $\begin{array}{l}40-64 \text { general } \\
\text { pop }^{n}\end{array}$ & Stroke or MI & $9 \cdot 58$ & $\begin{array}{c}9.82 \\
\text { (males) } \\
9.28 \\
\text { (females) }\end{array}$ & $\begin{array}{l}\text { OR males } 1.0(0.95, \\
\quad 1.06) \S \\
\text { OR females } 1.0(0.95, \\
1.10)\end{array}$ & No \\
\hline $\begin{array}{l}\text { Verhoef et al. (1994) } \\
\text { USA, } 5 \text { years }\end{array}$ & 100 & 109 & 427 & $\begin{array}{l}\text { 40-84 US } \\
\text { physicians }\end{array}$ & Ischaemic stroke & $11 \cdot 1$ & $10 \cdot 6 \mathrm{NS}$ & OR $1 \cdot 2(0 \cdot 7,2 \cdot 0) \|$ & No \\
\hline $\begin{array}{l}\text { Arnesen et al. }(1995) \\
\text { Norway, } 3.5 \text { years }\end{array}$ & 50 & 123 & 492 & $\begin{array}{l}12-61 \text { general } \\
\text { pop }^{n}\end{array}$ & $\begin{array}{r}\text { CHD event or } \\
\text { CHD death }\end{array}$ & $12 \cdot 7$ & $11 \cdot 3^{\star *}$ & $\begin{array}{l}\text { RR for CHD } 1.32 \\
\quad(1.05,1.65) \Upsilon\end{array}$ & Yes \\
\hline $\begin{array}{l}\text { Perry et al. (1995) } \\
\text { UK, } 12 \cdot 8 \text { years }\end{array}$ & 100 & 107 & 118 & $\begin{array}{l}\text { 40-59 general } \\
\text { pop }^{n}\end{array}$ & $\begin{array}{l}\text { Fatal and non- } \\
\text { fatal stroke }\end{array}$ & $13 \cdot 7$ & $11 \cdot 9^{* *}$ & $\begin{array}{l}\text { RR of stroke } 4.7(1.1, \\
20 \cdot 0) \dagger \dagger\end{array}$ & Yes \\
\hline $\begin{array}{l}\text { Chasan-Taber et al. } \\
\quad \text { (1996) } \\
\text { USA, } 7.5 \text { years }\end{array}$ & 100 & 333 & 333 & $\begin{array}{l}\text { 40-84 US } \\
\text { physicians }\end{array}$ & $\begin{array}{l}\text { Acute MI or CHD } \\
\text { death }\end{array}$ & $N G$ & $N G$ & $\begin{array}{r}\text { RR of MI } 1.7 \\
\quad(0.9,3 \cdot 3) \ddagger\end{array}$ & No \\
\hline Evans et al. (1997) & 100 & 240 & 472 & 35-57 general & Non-fatal MI & $12 \cdot 6$ & $13 \cdot 1 \mathrm{NS}$ & OR for $\mathrm{CHD}$ death & No \\
\hline USA, < 7 (MI) or & $\mathrm{MI}$ & 93 & 186 & pop $^{n}$ & CHD death & $12 \cdot 8$ & (MI) & and MI $0.82(0.55$ & \\
\hline $11-17$ years (death) & Death & 147 & 286 & & & & $\begin{array}{l}12 \cdot 7 \mathrm{NS} \\
\text { (Death) }\end{array}$ & $1.54) \dagger †$ & \\
\hline $\begin{array}{l}\text { Ridker et al. (1997) } \\
\text { USA, } 10 \text { years }\end{array}$ & 100 & 145 & 646 & $\begin{array}{l}\text { 40-84 US } \\
\text { physicians }\end{array}$ & Incidence VTE & $11 \cdot 5$ & $10 \cdot 9 \mathrm{NS}$ & $\begin{array}{l}\text { RR idiopathic VTE } \\
2 \cdot 48 \ddagger(0 \cdot 97,6 \cdot 39)\end{array}$ & $\begin{array}{l}\text { Yes, } \\
\text { idiopathic } \\
\text { VTE }\end{array}$ \\
\hline $\begin{array}{l}\text { Verhoef et al. (1997a) } \\
\text { USA, } 9 \text { years }\end{array}$ & 100 & 149 & 149 & $\begin{array}{l}\text { 40-84 US } \\
\text { physicians }\end{array}$ & $\begin{array}{l}\text { Angina pectoris } \\
\text { with surgery }\end{array}$ & $10 \cdot 9$ & $10 \cdot 4 \mathrm{NS}$ & $\begin{array}{l}\text { OR for angina } \\
\text { pectoris } 1 \cdot 0 \neq \ddagger \\
(0.8,1 \cdot 4)\end{array}$ & $\begin{array}{l}\text { No } \\
\text { No }\end{array}$ \\
\hline $\begin{array}{l}\text { Folsom et al. (1998) } \\
\text { USA, 3.3 years }\end{array}$ & NG & 232 & 537 & $\begin{array}{l}\text { 45-64 general } \\
\text { pop }^{n}\end{array}$ & $\begin{array}{r}\text { CHD event or } \\
\text { CHD death }\end{array}$ & $8 \cdot 86$ & $8.53 \mathrm{NS}$ & $\begin{array}{c}\text { RR of CHD } 1.28 \\
(0.5,3 \cdot 2) \|\end{array}$ & Yes \\
\hline $\begin{array}{l}\text { Wald et al. (1998) } \\
\text { UK, } 8.7 \text { years }\end{array}$ & 100 & 229 & 1126 & $\begin{array}{l}\text { 35-61 general } \\
\text { pop }^{n}\end{array}$ & Death from IHD & $13 \cdot 1$ & $11 \cdot 8^{* * *}$ & $\begin{array}{c}\text { OR of death from IHD } \\
2.9+\dagger(2.04,4 \cdot 12)\end{array}$ & Yes \\
\hline $\begin{array}{l}\text { Bots et al. (1999) } \\
\text { The Netherlands, } 2 \cdot 7 \\
\text { years }\end{array}$ & 49 & 224 & 533 & $\begin{array}{l}>55 \text { general } \\
\text { pop }^{n}\end{array}$ & $\mathrm{Ml}$ and stroke & $\begin{array}{l}17 \cdot 3 \\
18 \cdot 4\end{array}$ & $\begin{array}{c}15 \cdot 2(\mathrm{Ml})^{\star *} \\
15 \cdot 2 \\
(\text { stroke })^{* *}\end{array}$ & $\begin{array}{l}\text { OR for MI } 2 \cdot 10 \\
(0 \cdot 88,5 \cdot 03) \| \\
\text { OR for stroke } 1.90 \\
(0.80,4 \cdot 48)\end{array}$ & Yes \\
\hline $\begin{array}{l}\text { Ridker et al. (1999) } \\
\text { USA, } 3 \text { years }\end{array}$ & 0 & 122 & 244 & $\begin{array}{l}59 \cdot 3 \text { (mean) } \\
\text { general popn }\end{array}$ & $\begin{array}{l}\text { MI, stroke, or } \\
\text { death due to } \\
\text { CV disease }\end{array}$ & $14 \cdot 1$ & $12 \cdot 4^{* *}$ & $\begin{array}{r}\mathrm{RR} \text { of } \mathrm{Ml} \text { or stroke } \\
4 \cdot 6 \ddagger(1 \cdot 7,12 \cdot 3)\end{array}$ & \\
\hline
\end{tabular}

CV, cardiovascular disease; MI, myocardial infarction; NG, not given; Pop ${ }^{n}$, population; VTE, venous thrombotic disease or thromboembolism.

${ }^{*} P<0.05,{ }^{* *} P<0.01,{ }^{* * *} P<0.001$.

$\dagger$ Multivariate adjusted.

$\ddagger>95$ th Percentile v. 90th percentile.

$\S$ Unit change in hcy.

II Quintile $5 \mathrm{v}$. quintile 1.

II Increase in hcy of $4 \mu \mathrm{mol} / \mathrm{l}$.

†† Quartile 4 v. quartile 1.

¥ Increase in hcy of $5 \mu \mathrm{mol} / \mathrm{l}$.

represents a relatively-well-nourished sample, and consequently their homocysteine levels may have been lower than those of the US population in general, which possibly reduced the likelihood of finding an association. Of the eleven cohort studies only two failed to find an increased risk of vascular disease associated with elevated homocysteine levels. One of these studies, by Sirrs et al. (1999) in haemodialysis patients, actually observed an inverse relationship between homocysteine levels and mortality, suggesting that lower homocysteine levels were actually associated with an increased risk of death. The follow-up period in this study, however, was very short. Bostom et al. (1997a) and Moustapha et al. (1998) both carried out similar studies in patients with end-stage renal disease, and both found elevated homocysteine levels to be an independent risk factor for vascular disease. The follow-up period of these studies, however, was twice as long as that employed by Sirrs et al. (1999). Sirrs et al. (1999) hypothesized that their findings could have reflected a transient depression in homocysteine levels before death, which was not observed in the studies that used a longer follow-up.

The fact that authors use different statistical methods for calculating odds ratios and relative risks makes interpretation and comparison of prospective studies difficult. In the Boushey et al. (1995) meta-analysis referred to earlier only three prospective studies were included, and a 
Table 2. Results from prospective cohort studies of homocysteine (Hcy) and vascular disease (Values for odds ratio (OR) and relative risk (RR) are given with $95 \% \mathrm{Cl}$ in parentheses)

\begin{tabular}{|c|c|c|c|c|c|c|c|c|c|}
\hline \multirow{2}{*}{$\begin{array}{l}\text { Study, country, } \\
\text { follow-up }\end{array}$} & \multirow{2}{*}{$\begin{array}{l}\text { Percent- } \\
\text { age of } \\
\text { males }\end{array}$} & \multirow{2}{*}{$\begin{array}{l}\text { Sample } \\
\text { size }\end{array}$} & \multirow{2}{*}{$\begin{array}{l}\text { No. of } \\
\text { events }\end{array}$} & \multirow{2}{*}{$\begin{array}{l}\text { Age (years), } \\
\text { type of patient }\end{array}$} & \multirow{2}{*}{ End point } & \multicolumn{2}{|c|}{ Hcy $(\mu \mathrm{mol} / \mathrm{l})$} & \multirow[b]{2}{*}{ OR or RR } & \multirow{2}{*}{$\begin{array}{l}\text { Hcy identified } \\
\text { as a risk } \\
\text { factor? }\end{array}$} \\
\hline & & & & & & Event & Non-event & & \\
\hline $\begin{array}{l}\text { Petri et al. (1996) USA, } \\
\quad 4.8 \text { years }\end{array}$ & 7 & 337 & 60 & 23-47 SLE & $\begin{array}{l}\text { Stroke, ATE or } \\
\text { VTE }\end{array}$ & $10 \cdot 3$ & $7 \cdot 41^{* *}$ & $\begin{array}{l}\text { OR stroke } 2.44(1.04, \\
5.75) \\
\text { OR ATE } 3.49(0.97, \\
12.54)\end{array}$ & Yes \\
\hline $\begin{array}{l}\text { Bostom et al. }(1997 b) \\
\text { USA, } 1.4 \text { years }\end{array}$ & 49 & 73 & 16 & 44-68 ESRD & $\begin{array}{l}\text { CV event and CV } \\
\text { death }\end{array}$ & $N G$ & $N G$ & $\begin{array}{l}\text { RR } 3.9(1.4,10.5)^{\mathrm{b}} \\
\text { age and sex } \\
\text { adjusted }\end{array}$ & Yes \\
\hline $\begin{array}{l}\text { Nygard et al. (1997a) } \\
\text { Norway, } 4.6 \text { years }\end{array}$ & 81 & 587 & 64 & $32-80$ CAD & All cause mortality & $N G$ & $N G$ & $\begin{array}{l}\text { All cause mortality } \\
\text { ratio } 4 \cdot 51 \S \\
(1 \cdot 2,16 \cdot 6)\end{array}$ & Yes \\
\hline $\begin{array}{l}\text { Massy et al. (1998) } \\
\text { France, } 6.75 \text { years }\end{array}$ & 63 & 79 & 9 & 43-59 RTR & CHD events & $15 \cdot 2$ & $13 \cdot 3 \mathrm{NS}$ & $N G$ & No \\
\hline $\begin{array}{l}\text { Moustapha et al. (1998) } \\
\text { USA, } 1.45 \text { years }\end{array}$ & 56 & 167 & 86 & 41-71 ESRD & $\begin{array}{l}\text { CHD events and } \\
\text { mortality }\end{array}$ & $43 \cdot 0$ & $26 \cdot 9^{*}$ & $\begin{array}{l}\text { RR CHD events and } \\
\text { death } 1.01(1.00, \\
1.01) \ddagger\end{array}$ & Yes \\
\hline $\begin{array}{l}\text { Stehouwer et al. (1998) } \\
\text { The Netherlands, } \\
10 \text { years }\end{array}$ & 100 & 878 & 162 & 64-84 elderly & MI, stroke & $N G$ & $N G$ & $\begin{array}{l}\text { RR for CHD death } \\
1.58(0.93,2.69) \|\end{array}$ & Yes \\
\hline $\begin{array}{l}\text { Sirrs et al. (1999) } \\
\quad \text { Canada, } 0.75 \text { years }\end{array}$ & 63 & 88 & 35 & 55-79 HD & VAF and death & 28.5 & $31 \cdot 0^{*}$ & $\begin{array}{c}\text { RR of death } 0.74 \\
(0.01,0.61) \|\end{array}$ & No \\
\hline $\begin{array}{l}\text { Taylor et al. (1999) } \\
\text { USA, } 2 \cdot 1 \text { years }\end{array}$ & 63 & 351 & 47 & $\begin{array}{c}\text { 40-80 LED or } \\
\text { CVD }\end{array}$ & $\begin{array}{l}\text { Progression CHD } \\
\text { and death }\end{array}$ & $N G$ & $N G$ & $\begin{array}{c}\text { RR of death } 2.02 \\
(1.23,3.51) \S\end{array}$ & Yes \\
\hline $\begin{array}{l}\text { Bostom et al. }(1999) \\
\text { USA, 9.9 years }\end{array}$ & 41 & 1947 & 165 & $\begin{array}{c}\text { 59-91 } \\
\text { general pop }\end{array}$ & Stroke & $N G$ & $N G$ & $\begin{array}{l}\text { RR } 1.82 \\
\quad(1 \cdot 14,2.91) \S\end{array}$ & Yes \\
\hline $\begin{array}{l}\text { Kark et al. (1999) Israel, } \\
\text { 9-11 years }\end{array}$ & 45 & 1788 & 405 & $\begin{array}{l}>50 \\
\text { general pop }\end{array}$ & $\begin{array}{l}\text { All cause and } \\
\text { cause-specific } \\
\text { mortality }\end{array}$ & $\begin{array}{l}13 \cdot 7 \\
11 \cdot 6\end{array}$ & $\begin{array}{c}12 \cdot 1{\text { (men })^{\star *}}^{\star *} \\
10.8 \\
\text { (women) }^{\star \star} \\
22.9 \ddagger\end{array}$ & $\begin{array}{l}\text { *Hazard ratio for all } \\
\text { cause mortality } \\
1.97(1.31,2.98) \emptyset\end{array}$ & Yes \\
\hline $\begin{array}{l}\text { Shemin et al. (1999) } \\
\text { USA, } 1.5 \text { years }\end{array}$ & 48 & 84 & 47 & $>50 \mathrm{HD}$ & $\begin{array}{l}\text { Vascular access } \\
\text { thrombosis }\end{array}$ & $26 \cdot 1$ & & $\begin{array}{l}\text { RR } 1.04 \\
\quad(1.01,1.06) \dagger\end{array}$ & Yes \\
\hline
\end{tabular}

ATE, arterial thrombotic disease; CAD, coronary artery disease; CV, cardiovascular disease; CVD, cerebrovascular disease; ESRD, end-stage renal disease; HD, haemodialysis patients; LED, lower-extremity occlusive disease; MI, myocardial infarction; NG, not given; RTR, renal transplant recipient; SLE, systemic lupus erythematosus; VAF, vascular access failure; VTE, venous thrombotic disease or thromboembolism.

* $P<0.05,{ }^{* *} P<0.01,{ }^{* * *} P<0.001$.

$\dagger$ Multivariate adjusted.

$\mp$ Unit change in Hcy.

§ Quartile 4 v. quartile 1.

II Tertile $3 v$. tertile 1 .

I Quintile $5 v$. quintile 1; for details of calculation of hazard ratio, see Kark et al. (1999).

substantial number have been published since. Another meta-analysis at this time would make interpretation of prospective studies much easier.

\section{Reference range for normal homocysteine}

\section{Adults}

The normal range of fasting homocysteine varies widely (Ueland et al. 1993), depending on the choice of sample population and statistical cut-off employed. Current reference ranges are defined by measuring homocysteine levels in control populations of individuals who are 'presumed' to be free of vascular disease. A statistical cutoff is then used to define the normal range. This cut-off, however, varies substantially; for example, the 80th, 90th and 95th percentiles, mean plus 2 SD deviations and mean plus 3 SD have all been used to define the normal homocysteine range. The reference range of Kang et al. (1992), who defined normal homocysteine level as 5-15 $\mu \mathrm{mol} / \mathrm{l}$, moderate hyperhomocysteinaemia as $15-30 \mu \mathrm{mol} / \mathrm{l}$, intermediate hyperhomocysteinaemia as $30-100 \mu \mathrm{mol} / \mathrm{l}$ and severe hyperhomocysteinaemia as $>100 \mu \mathrm{mol} / \mathrm{l}$, is widely accepted. Ubbink et al. (1995) suggested that the reference range should be defined according to the homocysteine levels found in a population with an optimum supply of B-vitamin cofactors, because they play such an important role in determining homocysteine levels. Under these conditions, these authors proposed a reference range for normal homocysteine of $4.7-11.7 \mu \mathrm{mol} / 1$, which was based on the concentrations obtained after various B-vitamin supplementation trials. Clearly, more work is needed to establish an internationally-applicable reference range for fasting plasma homocysteine concentrations. 


\section{Children and adolescents}

Until recently very little data existed on the homocysteine levels of children and adolescents. However, three studies (De Laet et al. 1999; Greenlund et al. 1999; Osganian et al. 1999), which included between them data on the homocysteine levels of more than 5000 children, have recently been published. Studies on children and adolescents generally agree that between the ages of 2 months and 19 years the homocysteine levels are approximately half those of adult values, and range from 4.9 to $7.4 \mu \mathrm{mol} / 1$ (Tonstad et al. 1996b; Reddy, 1997; Vilaseca et al. 1997; De Laet et al. 1999; Greenlund et al. 1999; Osganian et al. 1999). In adulthood, males tend to have higher homocysteine levels than females (Brattstrom et al. 1994; Nygard et al. 1995; Shimakawa et al. 1997). Studies in children and adolescents have found no difference between homocysteine levels of boys and girls (Tonstad et al. 1996a, 1997; Reddy, 1997; De Laet et al. 1999; Greenlund et al. 1999) until after puberty (Tonstad et al. 1997; Vilaseca et al. 1997; De Laet et al. 1999), when homocysteine levels tend to increase markedly and a male-female difference becomes apparent, probably as a result of increased muscle mass and sex hormone concentration at this stage of development. In terms of ethnic differences, Greenlund et al. (1999) found no differences between black and white children, but Ubbink et al. (1996) and Osganian et al. (1999) found higher homocysteine levels in blacks $v$. whites. It would be useful to have some longitudinal studies which would assess the potential impact of homocysteine levels in childhood on coronary artery disease risk in later life.

\section{Main determinants of homocysteine levels}

\section{Inherited genetic defects}

Genetic defects in the key enzymes required for homocysteine metabolism can cause either a severe elevation in homocysteine levels, known as homocystinuria, or a more moderate accumulation of homocysteine, known as hyperhomocysteinaemia.

Homocystinuria. Deficiency of the trans-sulfuration enzyme cystathionine $\beta$-synthase is the most common cause of homocystinuria worldwide (Mudd et al. 1995). It is inherited as an autosomal recessive trait, the prevalence of which varies from 1:65 000 in Ireland to 1:900 000 in Japan, with an overall prevalence of 1:335000 (Naughton et al. 1998). The most common clinical features include dislocation of the optic lens, osteoporosis, thinning and lengthening of long bones, mental retardation, thromboembolism and premature vascular disease. The extent of these clinical symptoms varies from patient-to-patient owing to considerable genetic heterogeneity. Approximately $50 \%$ of affected patients respond to vitamin $\mathrm{B}_{6}$ supplementation, which decreases plasma methionine levels to normal and results in virtual elimination of homocysteine from the urine (Mudd et al. 1995). The number of possible mutations in the cystathionine $\beta$-synthase gene is currently estimated to be sixty-four (Kraus, 1998). The two most common mutations are G307S, which confers pyridoxine non-responsiveness and seems to be Celtic in origin, and $1278 \mathrm{~T}$ which confers pyridoxine responsiveness. The overall frequency of the G307S mutation amongst patients with homocystinuria is $31 \%$ (although it is found in $71 \%$ of Irish homocystinuric alleles) and the overall frequency of the $1278 \mathrm{~T}$ mutation is $24 \%$. Even rarer causes of homocystinuria result from deficiencies of MTHFR (Rosenblatt, 1995) and methionine synthase enzymes (Cb1E or G; Fenton \& Rosenberg, 1995), from defective synthesis of methylcobalamin and adenosylcobalamin ( Cb1C and D; Fenton \& Rosenberg, 1995), and from defective release of hydroxycobalamin from lysosomes (Cb1F; Fenton \& Rosenberg, 1995). These severe genetic defects are associated with homocysteine levels as high as 200-400 $\mu \mathrm{mol} / \mathrm{l}$ (Goodman et al. 1970; Levy et al. 1970).

Hyperhomocysteinaemia. All the previously mentioned mutations are very rare, and are associated with severely elevated homocysteine levels presenting as homocystinuria. Several years ago a common enzymic defect in the enzyme MTHFR, which is associated with mild elevations in plasma homocysteine levels (hyperhomocysteinaemia), was identified (Frosst et al. 1995). This mutation in MTHFR is autosomal recessive, and is characterized by a $\mathrm{C} \rightarrow \mathrm{T}$ substitution at base pair 677 resulting in an alanine to valine substitution. This variant is associated with lower enzyme activity in vivo (approximately $30 \%$ wild type), reduced activity after in vitro heating (hence, is often referred to as thermolabile MTHFR; Frosst et al. 1995) and a propensity for the enzyme to dissociate from its prosthetic group (FAD; Guenther et al. 1999) in individuals possessing the TT (homozygous) genotype. The frequency of homozygosity for the C677T polymorphism is generally between 5 and $18 \%$ (Motulsky, 1996; Heijmans et al. 1999); thus, in absolute terms this mutation affects a large number of individuals worldwide. Homozygous individuals (TT) seem to be more prone to elevated homocysteine levels than individuals without the thermolabile variant $(\mathrm{CC}$; Harmon et al. 1996; Jacques et al. 1996; Ma et al. 1996; Brattstrom et al. 1998; Gudnason et al. 1998). This elevation, however, appears to be mediated by folate status (Harmon et al. 1996; Jacques et al. 1996; Ma et al. 1996). Studies have shown that when folate status is good no detectable difference in homocysteine is found between different genotype groups. When folate status is low, however, homocysteine levels tend to be significantly higher in TT individuals compared with CT or CC individuals (Harmon et al. 1996; Jacques et al. 1996). This finding suggests that TT individuals may have a greater requirement for folate, since a greater intake of folate is needed to normalize homocysteine metabolism and represents a gene-nutrient interaction between folate and thermolabile MTHFR (Molloy et al. 1997; Rosenberg \& Rosenberg, 1998). It is still unclear if the moderate increase in homocysteine levels associated with the TT genotype is associated with an increased risk for vascular disease. For a comprehensive review of enzymic defects resulting in hyperhomocysteinaemia, see Brattstrom et al. (1998) and Bailey \& Gregory (1999).

\section{Disease states}

There are numerous disease states known to affect homocysteine levels, but it is beyond the scope of the present review to cover them all (for more details, see 
Ueland \& Refsum, 1989). Important among such conditions are renal disease, hyperproliferative disorders, organ transplantation and Alzheimer's disease. Hyperhomocysteinaemia is the most common cardiovascular risk factor in end-stage renal disease (Bostom \& Culleton, 1999). It is probable that the high prevalence of elevated homocysteine levels in renal disease occurs as a result of impaired renal homocysteine metabolism, since the kidney is estimated to be responsible for approximately $70 \%$ of daily homocysteine metabolism (Refsum et al. 1998a). A recent stable-isotope study by van Guldener et al. (1999) suggests that decreased activity of the remethylation pathway may be responsible for the hyperhomocysteinaemia encountered in renal disease. There is evidence of altered methionine metabolism in hyperproliferative disorders, such as cancer and psoriasis, resulting in elevated homocysteine levels, possibly as a result of a large burden of rapidly-dividing cells, or owing to occasional folate deficiency as a result of drug therapies such as methotrexate (Hoffman, 1985; Refsum et al. 1989, 1991; Ueland \& Refsum, 1989). Elevated homocysteine levels have also been consistently found in patients following renal or cardiac transplants (Ambrosi et al. 1994; Massy et al. 1994, 1998; Berger et al. 1995; Arnadottir et al. 1996; Gupta et al. 1998). It is possible that this elevation occurs as a result of impaired B-vitamin status or impaired renal function owing to immunosuppressants, or a combination of both (Jacobsen, 1998). Recently, serum homocysteine has been found to be significantly higher $(P<0 \cdot 001)$ in patients with Alzheimer's disease than in control populations of elderly people with no evidence of cognitive impairment (Clarke et al. 1998). This finding has led to the proposal that hyperhomocysteinaemia may play a role in the pathogenesis of Alzheimer's disease (Clarke et al. 1998; Diaz-Arrastia, 1998; Fekkes et al. 1998; McCaddon et al. 1998; Miller, 1999).

\section{Drug therapy}

There are many drugs that affect homocysteine metabolism, either directly or indirectly, by altering the metabolism of its vitamin cofactors. It is beyond the scope of the present review to give details of all the relevant drugs (for more details, see Ueland \& Refsum, 1989; Refsum et al. 1998b), and only a few key drugs which affect homocysteine levels are given here. Drugs associated with an increase in homocysteine levels include: methotrexate, a folate antagonist, which inhibits the enzyme dihydrofolate reductase (Refsum et al. 1986, Refsum \& Ueland, 1990; Quinn et al. 1998; Morgan et al. 1998); $\mathrm{N}_{2} \mathrm{O}$, which inactivates vitamin $\mathrm{B}_{12}$ (Ermens et al. 1991; Christensen et al. 1993; Badner et al. 1998); 6-azauridine triacetate, which is a vitamin $B_{6}$ antagonist (Slavik et al. 1969, 1982); and anticonvulsant therapy which alters folate metabolism by mechanisms which are not clearly understood (Ueland \& Refsum, 1989; Schwaninger et al. 1999). Other drugs associated with a reduction in homocysteine levels include aminothiols such as penicillamine and acetylcysteine (Kang et al. 1982, 1986b; Wiklund et al. 1996), and oral contraceptives and hormone therapy (Brattstrom et al. 1992a; van der Mooren et al. 1994; Anker et al. 1995).

\section{Age and sex}

Premenopausal women tend to have lower homocysteine levels compared with young men. After the menopause female homocysteine levels become more comparable with those of the male (Boers et al. 1983; Brattstrom et al. 1985, 1990; Kang et al. 1986a; Wouters et al. 1995; Verhoef et al. 1999). It is well established that homocysteine levels increase with age (Kang et al. 1986a; Andersson et al. 1992; Brattstrom et al. 1992a, 1994; Selhub et al. 1993; Robinson et al. 1995; Nygard et al. 1995, 1998; Vilaseca et al. 1997); this increase may be due to a decline in renal function (Brattstrom et al. 1994; Wu et al. 1994) or intake and status of the B-vitamin cofactors (Selhub et al. 1993; Brattstrom et al. 1994; Koehler et al. 1996) with increasing age.

\section{Lifestyle}

Recently, data from the Hordaland Homocysteine Study (Nygard et al. 1995, 1997b, 1998) has shown that smoking, high coffee consumption and lack of exercise are associated with an elevated plasma homocysteine level. Smoking and coffee consumption were found to influence plasma homocysteine concentration even in subjects with high folate status (Nygard et al. 1998), and the association between high coffee consumption and elevated plasma homocysteine did not disappear after adjustment for confounding factors such as smoking, lower multivitamin use and lower intake of fruit and vegetables (Nygard et al. 1997b; StolzenbergSolomon et al. 1999).

Homocysteine levels are influenced by the status of the B-vitamin cofactors involved in homocysteine metabolism, and such influences will now be discussed in detail.

\section{Treatment and prevention of hyperhomocysteinaemia}

\section{Folate}

A strong inverse relationship exists between folate status and homocysteine levels (Kang et al. 1987; Israelsson et al. 1988; Andersson et al. 1992; Selhub et al. 1993; Ueland et al. 1993; Brattstrom et al. 1994); this finding is not surprising since folate, in the form of 5-methyltetrahydrofolate, acts as a co-substrate for the remethylation of homocysteine. Hyperhomocysteinaemia has been found in subjects who have a folate status which is normal or low within the normal range, as well as in subjects with a subnormal folate status (Kang et al. 1987; Selhub et al. 1993; Ueland et al. 1993). Folic acid is also a very effective homocysteine-lowering agent. Clarke \& Homocysteine Lowering Trialists' Collaboration (1998) recently carried out a meta-analysis of randomized controlled trials that assessed the effects of folic acid-based therapies on homocysteine levels. Results of this meta-analysis clearly showed that of the three B-vitamins most commonly used in these trials (vitamin $\mathrm{B}_{6}$, vitamin $\mathrm{B}_{12}$ and folic acid), folic acid had the most profound homocysteine-lowering effect, resulting in a reduction of $25 \%$ on average. This meta-analysis also showed that the homocysteine-lowering effect was similar when doses ranged from 0.5 to $5 \mathrm{mg} / \mathrm{d}$. Doses of folic acid as low as $200 \mu \mathrm{g} / \mathrm{d}$ appear to effectively lower homocysteine levels in both hyperhomocysteinaemic 
(Guttormsen et al. 1996) and normohomocysteinaemic subjects (Ward et al. 1997) where this dose was shown to be optimal, although $100 \mu \mathrm{g} / \mathrm{d}$ produced significant $(P<0 \cdot 001)$ lowering of homocysteine levels. However, higher doses of folic acid may be required to lower homocysteine levels in certain disease states such as renal failure (Bostom \& Culleton, 1999). It should be noted, however, that subjects will not respond maximally to folic acid supplementation unless vitamin $\mathrm{B}_{12}$ status is adequate (Allen et al. 1990; Landgren et al. 1995); this finding reflects the interdependence of folate and vitamin $\mathrm{B}_{12}$ as co-substrate and cofactor respectively in homocysteine remethylation. If homocysteine is viewed as a functional indicator of folate status, then it seems probable that current definitions of 'normal' folate status may be inadequate, since folic acidresponsive homocysteine levels are found in individuals who have what is currently defined as 'normal' folate status (Ward et al. 1997). Whilst 'normal' folate status, as currently defined, may be adequate to ensure the absence of clinical signs of folate deficiency, it appears to be insufficient with respect to plasma homocysteine levels, and therefore is also not optimal in terms of potential risk of vascular disease. Evidence that an erythrocyte folate level of $>400 \mu \mathrm{g} / \mathrm{l}$ is required to give maximal protection from neural-tube defects (Daly et al. 1995) also supports the view that the current definition of 'normal' erythrocyte folate status may be too low. Given this new evidence regarding the relationships between folate status and plasma homocysteine levels and the risk of neural-tube defects, current dietary reference values should be revised.

\section{Vitamin $B_{12}$}

Many studies have been able to demonstrate an inverse relationship between vitamin $\mathrm{B}_{12}$ status and plasma homocysteine levels (Israelsson et al. 1988; Andersson et al. 1992; Selhub et al. 1993; Ueland et al. 1993; Brattstrom et al. 1994), although the strength of the correlation is not as strong as that observed between folate status and homocysteine levels. Vitamin $\mathrm{B}_{12}$ also effectively lowers plasma homocysteine levels at doses ranging from $6 \mu \mathrm{g}$ to $2 \mathrm{mg}$ (Rasmussen et al. 1996; Bronstrup et al. 1998; Clarke \& Homocysteine Lowering Trialists' Collaboration, 1998). An early study by Ubbink et al. (1994) found that the reduction in homocysteine levels achieved using a combination of folic acid $(0.65 \mathrm{mg})$, vitamin $\mathrm{B}_{6}(10 \mathrm{mg})$ and vitamin $\mathrm{B}_{12}(0.4 \mathrm{mg})$ supplementation was not significantly different from that achieved using folic acid alone. This finding suggested that there was no additional benefit to be gained from vitamin $B_{12}$ supplementation in terms of lowering homocysteine levels. However, since this study, a meta-analysis by Clarke \& Homocysteine Lowering Trialists' Collaboration (1998) has found that vitamin $\mathrm{B}_{12}$ supplementation produces an average $7 \%$ reduction in homocysteine levels. Also, Bronstrup et al. (1998) recently found that a combination of folic acid $(400 \mu \mathrm{g})$ and vitamin $\mathrm{B}_{12}(400 \mu \mathrm{g})$ supplementation for 4 weeks resulted in a lowering of homocysteine levels by $18 \%$ v. $11 \%$ produced by folic acid alone, again indicating that the combination of vitamin $\mathrm{B}_{12}$ and folic acid is more effective than folic acid alone.

\section{Vitamin $B_{6}$}

Vitamin $\mathrm{B}_{6}$ has been used for many years to successfully treat pyridoxine-responsive homocystinuria caused by cystathionine $\beta$-synthase deficiency (Mudd et al. 1985), but its role in the prevention or treatment of hyperhomocysteinaemia is still uncertain. Intervention studies indicate that vitamin $\mathrm{B}_{6}$ is effective in reducing the abnormally high homocysteine concentrations observed after a methionine load in subjects with hyperhomocysteinaemia (Dudman et al. 1993b; Franken et al. 1994; Bostom et al. 1997a). However, results from nine studies investigating the effect of vitamin $\mathrm{B}_{6}$ alone on fasting homocysteine levels are inconclusive (summarized in Table 3). To date, only two studies (Lakshmi \& Ramalakshmi, 1998; Mansoor et al. 1999) have found a significant lowering of fasting homocysteine levels following vitamin $\mathrm{B}_{6}$ supplementation. The study of Lakshmi \& Ramalakshmi (1998) was carried out in young women who had clinical and biochemical vitamin $\mathrm{B}_{6}$ deficiency. Ten volunteers received $20 \mathrm{mg}$ pyridoxine hydrochloride daily for $15 \mathrm{~d}$, which resulted in a reduction in fasting homocysteine levels of $19.7 \%$ (from 14.7 to $11.8 \mu \mathrm{mol} / \mathrm{l}, P<0 \cdot 05)$. However, the trial was not conducted 'blind' nor was it placebo-controlled, and there was no washout period. The study of Mansoor et al. (1999) was carried out in a group of nine healthy people who took $120 \mathrm{mg}$ vitamin $\mathrm{B}_{6}$ daily for 5 weeks. This regimen resulted in a significant $(17 \% ; P=0.011)$ lowering of plasma homocysteine levels. All the intervention studies discussed here were carried out using volunteers aged between 18 and 60 years. It is surprising that no vitamin $B_{6}$ intervention has been carried out in elderly subjects, as vitamin $\mathrm{B}_{6}$ status is known to decline with age (Hamfelt \& Soderhjelm, 1988; Reynolds et al. 1988), and plasma homocysteine levels are known to increase with age (Kang et al. 1986a; Andersson et al. 1992; Brattstrom et al. 1992a, 1994; Selhub et al. 1993; Robinson et al. 1995; Nygard et al. 1995, 1998; Vilaseca et al. 1997). It is possible that the general failure of studies to date to demonstrate a lowering in fasting homocysteine levels in response to vitamin $\mathrm{B}_{6}$ may have been as a result of suboptimal folate or vitamin $B_{12}$ status, which resulted in low S-adenosyl methionine levels, favouring homocysteine remethylation while inhibiting transsulfuration (Selhub \& Miller, 1992).

A relationship between suboptimal vitamin $\mathrm{B}_{6}$ status and vascular disease is well-supported in the literature (Rinehart \& Greenberg, 1949; Schroeder, 1955; Robinson et al. 1995, 1998; Chasan-Taber et al. 1996; Verhoef et al. 1996; Rimm et al. 1998). It is still unknown if vitamin $\mathrm{B}_{6}$ exerts its effect on vascular disease directly through its various effects on platelets (Subbarao et al. 1979; Konecki \& Feinberg 1980; Lam et al. 1980), connective tissue (Murray et al. 1978; Myers et al. 1985) and thromobogenesis (Editorial, 1981; Hladovec, 1979), or indirectly by causing the accumulation of homocysteine (Mudd et al. 1995). Many studies have found a significant $(P<0.05)$ inverse relationship between homocysteine levels and vitamin $\mathrm{B}_{6}$ status (Brattstrom et al. 1992b, Stampfer et al. 1992; Selhub et al. 1993; Robinson et al. 1995, 1998; Verhoef et al. 1996, 1997a; Graham et al. 1997; Osganian et al. 1999) and an accumulation of homocysteine in vitamin $\mathrm{B}_{6}$ depletion-repletion studies 
Table 3. Effect of vitamin $B_{6}$ supplementation on fasting homocysteine levels

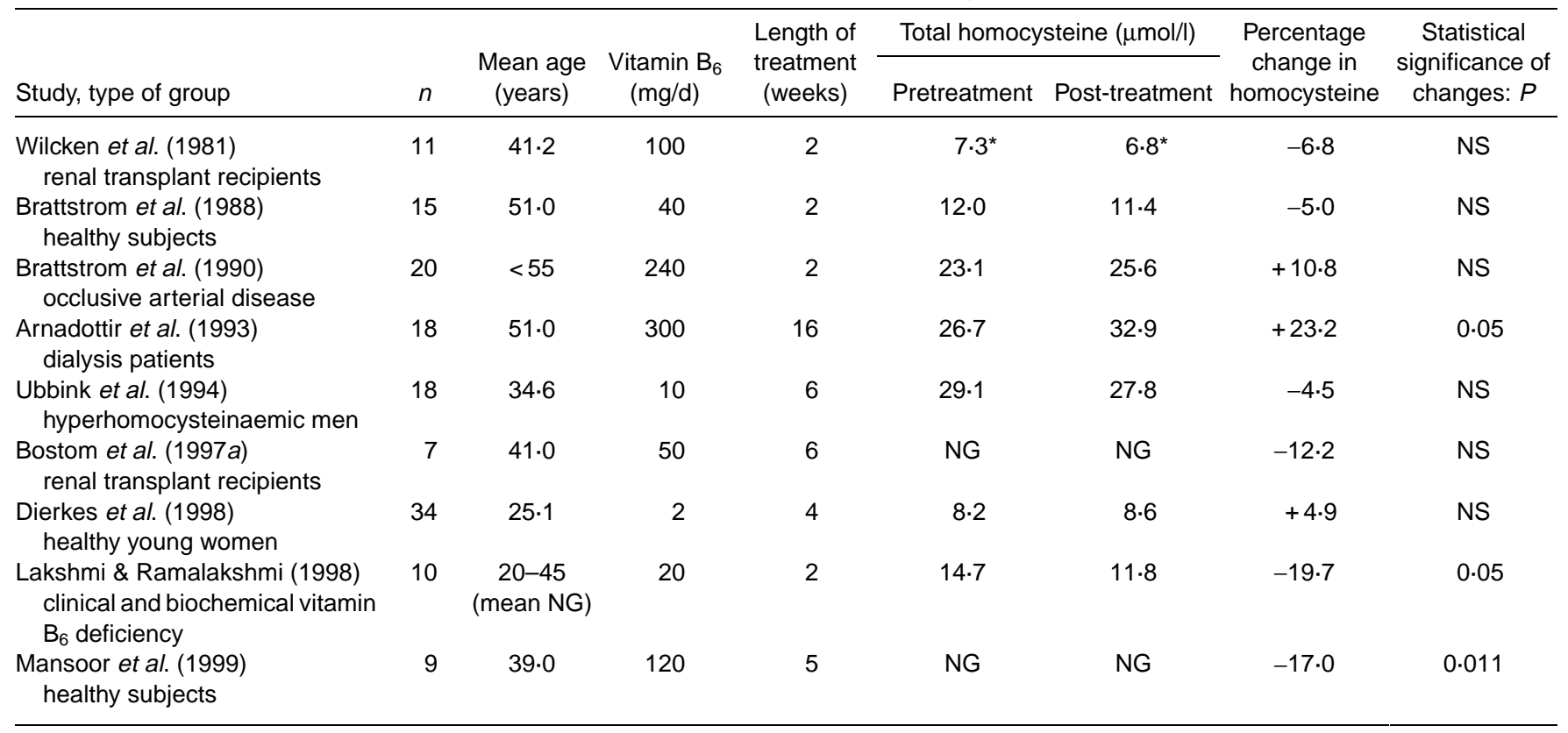

${ }^{*}$ Measurement of cysteine-homocysteine mixed disulfide not total homocysteine. NG, not given.

(Smolin et al. 1983; Shultz \& Hansen, 1998), which would support an indirect relationship between vitamin $\mathrm{B}_{6}$ and vascular disease mediated via homocysteine. However, some studies have failed to find any relationship between vitamin $\mathrm{B}_{6}$ and homocysteine (Brattstrom et al. 1990; Dalery et al. 1995; Riggs et al. 1996; Ubbink et al. 1996; Dierkes et al. 1998; Healy et al. 1998; Bates et al. 1999), and the findings of vitamin $\mathrm{B}_{6}$ depletion-repletion studies are contradictory (Smolin et al. 1983; Miller et al. 1992; Stabler et al. 1997; Shultz \& Hansen, 1998). Thus, currently the relationship between vitamin $\mathrm{B}_{6}$ and plasma homocysteine remains unclear and requires further study, in particular in elderly populations.

\section{Riboflavin}

Riboflavin plays an essential role in both the remethylation and trans-sulfuration pathways of homocysteine metabolism. However, little information is available on the effect of riboflavin status on homocysteine levels. Riboflavin supplementation has only been included in two intervention studies (Olszewski et al. 1989; Lakshmi \& Ramalakshmi, 1998) where homocysteine was the primary end point. The first study, by Olszewski et al. (1989), involved treatment of twenty-one myocardial infarction patients with a combination of choline, troxerutin, vitamin $\mathrm{B}_{6}$, vitamin $\mathrm{B}_{12}$, folate and riboflavin for $21 \mathrm{~d}$. This study made it impossible to discover what effect, if any, riboflavin alone had on fasting homocysteine levels. The second study (Lakshmi \& Ramalakshmi, 1998) was carried out in women with clinical and biochemical riboflavin deficiency (mean erythrocyte glutathione reductase activation coefficient 1.80) who took a pharmacological dose of riboflavin $(10 \mathrm{mg}$ ) for $15 \mathrm{~d}$. This treatment resulted in an improvement in riboflavin status, but there was no significant change in plasma homocysteine levels. However, this study was poorly designed, was not conducted 'blind', had no placebo group or washout period, and the sample size was very small.

The importance of riboflavin for homocysteine metabolism has recently been highlighted by the characterization of the flavin-dependent enzyme MTHFR from Escherihia coli (Guenther et al. 1999). The wild-type enzyme and a mutant form of MTHFR, which is commonly known as thermolabile MTHFR, have both been characterized. Guenther et al. (1999) demonstrated that the thermolabile enzyme was approximately ten times more likely than the wild-type enzyme to dissociate from its FAD cofactor. They also found that the addition of folates to MTHFR in vitro stabilized the binding FAD in both the wild-type and mutant E. coli enzymes. Given the intimate involvement of riboflavin in both pathways of homocysteine metabolism and, in particular, the recent characterization of the thermolabile variant of MTHFR, which highlighted the importance of riboflavin, it is timely to investigate the effect of riboflavin supplementation on plasma homocysteine and to examine the interaction between riboflavin status, folate status and homocysteine levels in individuals with the TT genotype.

\section{Possible mechanisms for the vascular toxicity of hyperhomocysteinaemia}

The exact mechanism for the vascular toxicity of hyperhomocysteinaemia is still unknown; however, studies indicate it is both atherogenic and thrombogenic.

\section{Atherosclerotic mechanisms}

Effects on endothelial and smooth-muscle cells. Studies have shown that homocysteine is directly toxic to endothelial cells in a dose-dependent manner (Wall et al. 
1980; De Groot et al. 1983; Blann, 1992; Dudman 1999) and that this damage can be prevented by catalase, which indicates that the generation of $\mathrm{H}_{2} \mathrm{O}_{2}$ possibly from homocysteine auto-oxidation, is important in the pathological process (Starkebaum \& Harlan, 1986; Dudman et al. 1991; Emsley et al. 1999). Studies also indicate that elevated homocysteine is associated with a reduced ability to produce endothelium-derived relaxing factor (NO; Stamler et al. 1993; Upchurch et al. 1995; Loscalzo, 1996; Keaney \& Loscalzo, 1997; Welch et al. 1997). Studies using cultured endothelial cells from animals and human subjects have all found impaired endothelium-dependent vasodilatation in association with mild-to-moderate hyperhomocysteinaemia (Celermajer et al. 1993; van den Berg et al. 1995, Lentz et al. 1996; Upchurch et al. 1996; Tawakol et al. 1997), indicating that homocysteine interferes with the relaxing action of NO on the blood vessel wall. Elevated homocysteine levels have also been shown to stimulate vascular smooth muscle cells to proliferate and synthesize collagen, while at the same time impeding the regeneration of endothelial cells, hallmarks of atherosclerosis (Harker et al. 1983; Tsai et al. 1994, 1996). Welch et al. (1997) proposed that smooth-muscle cell proliferation was induced as a direct result of the inactivation of NO by lipid peroxides, which have themselves been formed as a result of the auto-oxidation of homocysteine (Garg \& Hassid, 1989; Marks et al. 1995).

Oxidative effects. Several in vitro studies indicate increased oxidant stress in response to hyperhomocysteinaemia (Stamler et al. 1993; Loscalzo, 1996; Outinen et al. 1998; Voutilainen et al. 1998). However, in vivo studies are contradictory (Dudman et al. 1993a; Mansoor et al. 1995; Young et al. 1997). Homocysteine readily undergoes auto-oxidation in plasma (Velury \& Howell, 1988; Stamler et al. 1993; Andersson et al. 1995) forming reactive oxygen species such as $\mathrm{H}_{2} \mathrm{O}_{2}$ and superoxide, which may themselves cause oxidation of LDL (Heinecke et al. 1987), and other products such as cysteinehomocysteine mixed disulfides, and homocysteine thiolactone. It has been proposed that homocysteine thiolactone reacts with LDL to form LDL-homocysteine thiolactone aggregates, which may then be taken up by macrophages and subsequently incorporated into foam cells in early atherosclerotic plaques (Naruszewicz et al. 1994; Jakubowski, 1997; Ferguson et al. 1999). It has also shown that homocysteine can inhibit the synthesis of glutathione peroxidase (Upchurch et al. 1995, 1997) which detoxifies $\mathrm{H}_{2} \mathrm{O}_{2}$ and lipid peroxides, thereby leaving the cell vulnerable to oxidative damage. Also, work by several authors suggests that lipid peroxidation, as a result of elevated homocysteine levels, may then cause decreased expression of the enzyme nitric oxide synthase and directly degrade NO (Heinecke et al. 1987; Chin et al. 1992; Liao et al. 1995; Blom et al. 1995; Domagala et al. 1997)

\section{Thrombotic mechanisms}

Coagulant pathway. Elevated homocysteine levels in vitro have been shown to upset the balance of certain factors within the coagulation pathway, including activation of factors V and X11 (Ratnoff, 1968; Rodgers \& Kane, 1986).
Elevated homocysteine in vitro also increased platelet adhesion and thromboxane production, inhibited prostacyclin synthesis (Harker et al. 1974, 1976; Graeber et al. 1982; Wang et al. 1993), and stimulated tissue factor synthesis (Fryer et al. 1993; Rodgers et al. 1993).

Anticoagulant pathway. Elevated homocysteine levels in vitro are associated with the following effects on the anticoagulant pathway: suppression of protein C activation (Rodgers \& Conn, 1990; Lentz \& Sadler, 1991; Hayashi et al. 1992); down regulation of thrombomodulin expression (Lentz \& Sadler, 1991; Hayashi et al. 1992; Lentz et al. 1996); suppression of heparan sulfate expression (Nishinaga et al. 1993); inhibition of von Willebrand factor synthesis (Lentz \& Sadler, 1993; Lubec et al. 1996; Freyburger et al. 1997).

Fibrinolytic pathway. In the fibrinolytic pathway, elevated homocysteine levels block the binding of tissue plasminogen activator to its endothelial cell receptor, annexin II (Hajjar, 1993; Hajjar et al. 1998), and enhances the binding between atherogenic lipoprotein lipoprotein (a) and fibrin even at low concentrations (Harpel et al. 1992).

The ultimate consequence of all these effects on the coagulant, anticoagulant and fibrinolytic pathways is a shift in the normal balance between coagulation and fibrinolysis, creating a pro-thrombotic environment which facilitates the formation of a thrombus.

There are, however, many problems associated with studies investigating the vascular toxicity of elevated homocysteine. Most studies use very high concentrations of homocysteine, sometimes even higher than those seen in severe homocystinuria, and their relevance to hyperhomocysteinaemia is uncertain. Some studies also use different forms of homocysteine, such as homocysteine thiolactone, which may be more toxic than homocysteine itself. Also, the effects observed in some studies are sometimes not shown to be specific to homocysteine, and may be observed with other S-containing amino acids, such as cysteine (Fryer et al. 1993; Nishinaga et al. 1993; Stamler et al. 1993; Tsai et al. 1994; Kokame et al. 1996). A further problem is that most of these studies have been carried out in vitro or in animals and their applicability in human subjects is unknown. Atherosclerosis is a very slow process which is difficult to mimic using short-term in vitro experiments. Finally, there is very little information available for human subjects on the effect on haemostatic factors, and the vasculature in general, of lowering homocysteine levels. Van den Berg et al. (1995) reported that lowering homocysteine levels in patients with peripheral arterial occlusive disease following 1 year of folic acid and vitamin $\mathrm{B}_{6}$ therapy resulted in a lowering of thrombomodulin, von Willebrand factor and endothelin, which were all elevated at baseline, but there was no change in the status of tissue-type plasminogen activator or selectin, which were both normal at baseline. Also, Bellamy et al. (1999) in a double-blind placebo-controlled crossover study involving eighteen subjects with homocysteine levels $>13 \mu \mathrm{mol} / \mathrm{l}$, found that folate supplementation $(5 \mathrm{mg} / \mathrm{d}$ for 6 weeks $)$ reduced homocysteine levels and enhanced endothelium-dependent responses. In contrast to this finding, van Guldener et al. (1998) reported no improvement in thrombomodulin, E-selectin, plasmin activator inhibitor-1 or tissue-type 
plasmin activator endothelin after 1 year of folic acid therapy in a group of thirty peritoneal dialysis patients.

\section{Concluding statement}

The present review has highlighted many areas that require further research. Definitions of normal reference ranges for both adults and children require further clarification. More research, especially in vivo, is essential to explore the mechanism by which homocysteine damages the vasculature, as well as to examine if lowering homocysteine levels in vivo is beneficial in terms of improving haemostatic variables. Further work is also necessary to find the combination of B-vitamins that most effectively lowers homocysteine levels, and to investigate the homocysteinelowering capacity of riboflavin, which is intimately involved in homocysteine metabolism but has so far received little attention.

The effect of homocysteine on vascular disease is a graded effect (Arnesen et al. 1995; Perry et al. 1995; Nygard et al. 1997a); therefore, decreasing homocysteine levels is likely to be beneficial, even if the levels are currently defined as 'normal'. If B-vitamin supplementation is to form part of a public health strategy aimed at vascular disease prevention in the general population, it is vital that the lowest effective dose (and combination) of B-vitamins that will result in the greatest lowering of homocysteine levels is found so that the risk of overexposure is limited. Thus, further intervention trials that investigate the effect of very low doses of B-vitamins on fasting homocysteine levels, are vital. The United States Department of Health and Human Services (Food and Drug Administration, 1996) recently implemented a policy to fortify all grain products with folic acid at a level of $1.4 \mu \mathrm{g} / \mathrm{g}$ product. Although the primary aim of this strategy was to prevent neural-tube defects, it is hoped that the fortification policy will also be beneficial in terms of vascular disease prevention. Jacques et al. (1999) have already demonstrated a significant improvement in folate status, and a corresponding lowering of plasma homocysteine levels, as a direct result of this fortification policy. The topic of fortification in the UK is still controversial, mainly because of the fear that folic acid supplementation would correct the pernicious anaemia associated with vitamin $B_{12}$ deficiency but allow the neurological damage to progress, thus putting certain subgroups of the population at risk (Savage \& Lindenbaum, 1995).

Ultimately what is needed is a large-scale randomized placebo-controlled primary prevention trial which will establish whether lowering homocysteine levels has a favourable effect on the incidence of vascular disease. No such trial is planned currently because of the huge expense involved, but several secondary prevention trials are already underway (Eikelboom et al. 1999), and the first results are expected in a few years.

\section{References}

Alfthan G, Pekkanen J, Jauhiainen M, Pitkaniemi J, Karvonen M, Tuomilehto J, Salonen JT \& Ehnholm C (1994) Relation of serum homocysteine and lipoprotein (a) concentrations to atherosclerotic disease in a prospective Finnish population based study. Atherosclerosis 106, 9-19.

Allen RH, Stabler SP, Savage DG \& Lindenbaum J (1990) Diagnosis of cobalamin deficiency I: Usefulness of serum methylmalonic acid and total homocysteine concentration. American Journal of Hematology 34, 90-98.

Ambrosi P, Barlatier A, Habib G, Garcon D, Kreitman B, Roland PH, Saingra S, Metras D \& Luccioni R (1994) Hyperhomocysteinaemia in heart transplant recipients. European Heart Journal 15, 1191-1195.

Andersson A, Brattstrom L, Israelsson B, Isaksson A, Hamfelt A \& Hultberg B (1992) Plasma homocysteine before and after methionine loading with regard to age, gender, and menopausal status. European Journal of Clinical Investigation 22, 79-87.

Andersson A, Lindgren A \& Hultberg B (1995) Effect of thiol oxidation and thiol export from erythrocytes on determination of redox status of homocysteine and other thiols in plasma from healthy subjects and patients with cerebral infarction. Clinical Chemistry 41, 361-366.

Anker G, Lonning PE, Ueland PM, Refsum H \& Lien EA (1995) Plasma levels of the atherogenic amino acid homocysteine in post-menopausal women with breast cancer treated with tamoxifen. International Journal of Cancer 60, 365-368.

Arnadottir M, Brattstrom L, Simonsen O, Thysell H, Hultberg B, Andersson A \& Nillson-Ehle P (1993) The effect of high-dose pyridoxine and folic acid supplementation on serum lipid and plasma homocysteine concentrations in dialysis patients. Clinical Nephrology 40, 236-240.

Arnadottir M, Hultberg B, Vladov V, Nisson-Ehle P \& Thysell H (1996) Hyperhomocysteinemia in cyclosporin-treated renal transplant recipients. Transplantation 61, 509-512.

Arnesen E, Refsum H, Bonaa KH, Ueland PM, Forde OH \& Nordrehaug JE (1995) Serum total homocysteine and coronary heart disease. International Journal of Epidemiology 24, 704709.

Aronow WS \& Ahn C (1997) Association between plasma homocysteine and coronary artery disease in older persons. American Journal of Cardiology 80, 1216-1218.

Aronow WS \& Ahn C (1998) Association between plasma homocysteine and peripheral arterial disease in older persons. Coronary Artery Disease 9, 49-50.

Badner NH, Drader K, Freeman D \& Spence JD (1998) The use of intraoperative nitrous oxide leads to postoperative increases in plasma homocysteine. Anesthesia and Analgesia 87, 711-713.

Bailey LB \& Gregory JF (1999) Polymorphisms of methylenetetrahydrofolate reductase and other enzymes: metabolic significance risks and impact on folate requirement. Journal of Nutrition 129, 919-922.

Bates CJ \& Fuller NJ (1986) The effect of riboflavin deficiency on methylenetetrahydrofolate reductase (NADPH) (EC 1.5.1.20) and folate metabolism in the rat. British Journal of Nutrition $\mathbf{5 5}$, 455-464.

Bates CJ, Pentieva KD, Prentice A, Mansoor MA \& Finch S (1999) Plasma pyridoxal phosphate and pyridoxic acid and their relationship to plasma homocysteine in a representative sample of British men and women aged 65 years and over. British Journal of Nutrition 81, 191-201.

Bellamy MF, McDowell IFW, Ramsey MW, Brownlee M, Newcombe RG \& Lewis MJ (1999) Oral folate enhances endothelial function in hyperhomocysteinaemic subjects. European Journal of Clinical Investigation 29, 659-662.

Berger PB, Jones JD, Olson LJ, Edwards BS, Frantz RP, Rodeheffer RJ, Kott BA, Daly RC \& McGregor CGA (1995) Increase in total plasma homocysteine concentration after cardiac-transplantation. Mayo Clinic Proceedings 70, 125-131.

Blann AD (1992) Endothelial cell damage and homocysteine. Atherosclerosis 94, 89-91. 
Blom HJ, Kleinveld HA, Boers GHJ, Demacker PNM, Hal-Lemmers HLM, Te Poele-Pothoff MTWB \& Trijbels JMF (1995) Lipid peroxidation and susceptibility of low-density lipoproteins to in vitro oxidation in hyperhomocysteinaemia. European Journal of Clinical Investigation 25, 149-154.

Boers GH, Smals AG, Trijbels FJ, Leermakers AI \& Kloppenborg PW (1983) Unique efficiency of methionine metabolism in premenopausal women may protect against vascular disease in the reproductive years. Journal of Clinical Investigation 72, 1971-1976.

Bostom AG \& Culleton BF (1999) Hyperhomocysteinemia in chronic renal disease. Journal of the American Society of Nephrology 10, 891-900.

Bostom AG, Gohh RY, Beaulieu AJ, Nadeau MR, Hume AL, Jacques PF, Selhub J \& Rosenberg IH (1997a) Treatment of hyperhomocysteinemia in renal transplant recipients: A randomized placebo-controlled trial. Annals of Internal Medicine 127, 1089-1092.

Bostom AG, Rosenberg IH, Silbershatz H, Jacques PF, Selhub J, D'Agostino RB, Wilson PWF \& Wolf PA (1999) Nonfasting plasma total homocysteine levels and stroke incidence in elderly persons: The Framingham Study. Annals of Internal Medicine 131, 352-355.

Bostom AG, Shemin D, Verhoef P, Nadeau MR, Jacques PF, Selhub J, Dworkin L \& Rosenberg IH (1997b) Elevated fasting plasma total homocysteine levels and cardiovascular disease outcomes in maintenance dialysis patients: A prospective study. Arteriosclerosis, Thrombosis and Vascular Biology 17, 2554-2558.

Bots ML, Launer LJ, Lindemans J, Hoes AW, Hofman A, Witteman JCM, Koudstaal PJ \& Grobbee DE (1999) Homocysteine and short-term risk of myocardial infarction and stroke in the elderly. Archives of Internal Medicine 159, 38-44.

Bots ML, Launer LJ, Lindemans J, Hofman A \& Grobbee DE (1997) Homocysteine, atherosclerosis and prevalent cardiovascular disease in the elderly: The Rotterdam study. Journal of Internal Medicine 242, 339-347.

Boushey CJ, Beresford SAA, Omenn GS \& Motulsky AG (1995) A quantitative assessment of plasma homocysteine as a risk factor for vascular disease. Journal of the American Medical Association 274, 1049-1057.

Brattstrom LE, Hardebo JE \& Hultberg BL (1984) Moderate hyperhomocysteinemia - A possible risk factor for arteriosclerotic cerebrovascular disease. Stroke 15, 1012-1016.

Brattstrom LE, Hultberg BL \& Hardebo JE (1985) Folic acid responsive postmenopausal homocysteinemia. Metabolism 34, 1073-1077.

Brattstrom LE, Israelsson B, Jeppsson JO \& Hultberg BL (1988) Folic acid - an innocuous means to reduce plasma homocysteine. Scandinavian Journal of Clinical Laboratory Investigation 48, 215-221.

Brattstrom L, Israelson B, Norrving B, Bergqvist D, Thorne J, Hultberg B \& Hamfelt A (1990) Impaired homocysteine metabolism in early-onset cerebral and peripheral occlusive arterial disease. Effects of pyridoxine and folic acid treatment. Atherosclerosis 81, 51-60.

Brattstrom L, Israelsson B, Olsson A, Andersson A \& Hultberg B (1992a) Plasma homocysteine in women on oral oestrogencontaining contraceptives and in men with oestrogen-treated prostatic carcinoma. Scandinavian Journal of Clinical Laboratory Investigation 52, 283-287.

Brattstrom L, Lindgren A, Israelsson B, Andersson A \& Hultberg B (1994) Homocysteine and cysteine: determinants of plasma levels in middle-aged and elderly subjects. Journal of Internal Medicine 236, 633-641.

Brattstrom L, Lindgren A, Israelsson B, Malinow MR, Norrving B, Upson B \& Hamfelt A (1992b) Hyperhomocysteinaemia in stroke: prevalence, cause, and relationships to type of stroke risk factors. European Journal of Clinical Investigation 22, 214-221.

Brattstrom L, Wilcken DEI, Ohrvik J \& Brudin L (1998) Common methylenetetrahydrofolate reductase gene mutation leads to hyperhomocysteinemia but not to vascular disease - the results of a meta-analysis. Circulation 98, 2520-2526.

Bronstrup A, Hages M, Prinz-Lagenohl R \& Pietrzik K (1998) Effect of folic acid and combinations of folic acid and vitamin B-12 on plasma homocysteine concentrations in healthy, young women. American Journal of Clinical Nutrition 68, 1104-1110.

Carson NAJ \& Neill DW (1962) Metabolic abnormalities detected in a survey of mentally backward individuals in Northern Ireland. Archives of Disease in Childhood 37, 505-513.

Celermajer DS, Sorensen K, Ryalls M, Robincon J, Thomas O, Leonard JV \& Deanfield JE (1993) Impaired endothelial function occurs in the systemic arteries of children with homozygous homocystinuria but not in their heterozygous parents. Journal of the American College of Cardiology 22, 854-858.

Chasan-Taber L, Selhub J, Rosenberg IH, Malinow MR, Terry P, Tishler PV, Willett W, Hennekens CH \& Stampfer MJ (1996) A prospective study of folate and vitamin B6 and risk of myocardial infarction in US physicians. Journal of the American College of Nutrition 15, 136-143.

Chin JH, Azhar S \& Hoffman BB (1992) Inactivation of endothelial derived relaxing factor by oxidised lipoprotein. Journal of Clinical Investigation 89, 10-18.

Christensen B, Guttormsen AB, Schneede J, Riedel B, Refsum H, Svardal A \& Ueland PM (1993) Preoperative methionine loading enhances restoration of the cobalamin-dependent enzyme methionine synthase after nitrous oxide anaesthesia. Anesthesiology 80, 1046-1056.

Clarke R, Daly L, Robinson K, Naughton E, Cahalane S, Fowler B \& Graham I (1991) Hyperhomocysteinemia: an independent risk factor for vascular disease. New England Journal of Medicine 324, 1149-1155.

Clarke R \& Homocysteine Lowering Trialists' Collaboration (1998) Lowering blood homocysteine with folic acid based supplements: meta-analysis of randomised trials. British Medical Journal 316, 894-898.

Clarke R, Smith AD, Jobst KA, Refsum H, Sutton L \& Ueland PM (1998) Folate, vitamin B12, and serum total homocysteine levels in confirmed Alzheimer's Disease. Archives of Neurology 55, 1449-1455.

Dalery K, Lussier-Cacan S, Selhub J, Davignon J, Latour Y \& Genest J (1995) Homocysteine and coronary artery disease in French Canadian subjects: Relation with vitamins B12, B6, pyridoxal phosphate, and folate. American Journal of Cardiology 75, 1107-1111.

Daly LE, Kirke PN, Molloy A, Weir DG \& Scott JM (1995) Folate levels and neural tube defects. Implications for prevention. Journal of the American Medical Association 274, 1698-1702.

De Groot PG, Willems C, Boers GHJ, Gonsalves MD, van Aken WG \& van Mourik JA (1983) Endothelial cell dysfunction in homocystinuria. European Journal of Clinical Investigation 13, 405-410.

De Laet C, Wautrecht J-C, Brausseur D, Dramaix M, Boeynaems J-M, Decuyper J \& Kahn A (1999) Plasma homocysteine concentrations in a Belgian school-age population. American Journal of Clinical Nutrition 69, 968-972.

Den Heijer M, Koster T, Blom HJ, Bos GMJ, Briet E, Reitsma PH, Vandenbroucke JP \& Rosenblatt FR (1996) Hyperhomocysteinemia as a risk factor for deep-vein thrombosis. New England Journal of Medicine 334, 759-762.

Diaz-Arrastia R (1998) Hyperhomocysteinemia: a new risk factor for Alzheimer's Disease? Archives of Neurology 55, 1407-1408.

Dierkes J, Kroesen M \& Pietrzik K (1998) Folic acid and vitamin B6 supplementation and plasma homocysteine concentrations in 
healthy young women. International Journal of Vitamin and Nutrition Research 68, 98-103.

Domagala TB, Libura M \& Szczeklik A (1997) Hyperhomocysteinemia following an oral methionine load is associated with increased lipid peroxidation. Thrombosis Research 87, 411-416.

Dudman NPB, Hicks C, Wang J \& Wilcken DEL (1991) Human arterial endothelial cell detachment in vitro: its promotion by homocysteine and cysteine. Atherosclerosis 91, 77-83.

Dudman NPB, Temple SE, Guo XW, Fu W \& Perry MA (1999) Homocysteine enhances neutrophil-endothelial interactions in both cultured human cells and rats in vivo. Circulation Research 84, 409-416.

Dudman NPB, Wilcken DEL \& Stocker R (1993a) Circulating lipid hydroperoxide levels in human hyperhomocysteinemia: Relevance to development of arteriosclerosis. Arteriosclerosis and Thrombosis 13, 512-516.

Dudman NPB, Wilcken DEL, Wang J, Lynch JF, Macey D \& Lundberg P (1993b) Disordered methionine/homocysteine metabolism in premature vascular disease: its occurrence, cofactor therapy, and enzymology. Arteriosclerosis and Thrombosis 13, 1253-1260.

Du Vigneaud VE (1952) Trail of Research in Sulfur Chemistry and Metabolism, and Related Fields. Ithaca, NY: Cornell University Press.

Editorial (1981) Is vitamin B-6 an anti-thrombotic agent? Lancet i, 1299.

Eichinger S, Stumpflen A, Hirschi M, Bialonczyk C, Herkner K, Stain M, Schneider B, Pabinger I, Lechner K \& Kyrle AA (1998) Hyperhomocysteinemia is a risk factor for recurrent venous thromboembolism. Thrombosis and Haemostasis 80, 566-569.

Eikelboom JW, Lonn E, Genest J, Hankey G \& Yusuf S (1999) Homocyst(e)ine and cardiovascular disease: A critical review of the epidemiologic evidence. Annals of Internal Medicine 131, 363-375.

Emsley AM, Jeremy JY, Gomes GN, Angeline GD \& Plane F (1999) Investigation of the inhibitory effects of homocysteine and copper on nitric oxide-mediated relaxation of rat isolated aorta. British Journal of Pharmacology 126, 1034-1040.

Ermens AAM, Refsum H \& Rupreht J (1991) Monitoring cobalamin inactivation during nitrous oxide anesthesia by determination of homocysteine and folate in plasma and urine. Clinical Pharmacological Therapy 49, 385-393.

Evans RW, Shaten J, Hempel JD, Cutler JA \& Kuller LH (1997) Homocyst(e)ine and risk of cardiovascular disease in the multiple risk factor intervention trial. Arteriosclerosis, Thrombosis and Vascular Biology 17, 1947-1953.

Fekkes D, van der Cammen TJM, van Loon CPM, Verschoor C, van Harskamp F, de Koning I, Schudel WJ \& Pepplinkhuizen L (1998) Abnormal amino acid metabolism in patients with early stage Alzheimer dementia. Journal of Neural Transmission 105, 287-294.

Fenton WA \& Rosenberg LE (1995) Inherited disorders of cobalamin transport and metabolism. In The Metabolic Basis of Inherited Disease, 7th ed., pp. 3129-3149 [CR Scriver, AL Beaudet, WS Sly and D Valle, editors]. New York: McGraw-Hill.

Ferguson E, Hogg N, Antholine WE, Joseph J, Singh RJ, Parthasarathy S \& Kalyanaraman B (1999) Characterization of the adduct formed from the reaction between homocysteine thiolactone and low-density lipoprotein: Antioxidant implications. Free Radical Biology and Medicine 26, 968-977.

Finkelstein JD (1990) Methionine metabolism in mammals. Journal of Nutritional Biochemistry 1, 228-237.

Folsom AR, Nieto J, McGovern PG, Tsai MY, Malinow MR, Eckfeldt JH, Hess DL \& Davis CE (1998) Prospective study of coronary heart disease incidence in relation to fasting total homocysteine, related genetic polymorphisms, and B vitamins:
The atherosclerosis risk in communities (ARIC) study. Circulation 98, 204-210.

Food and Drug Administration (1996) Food standards: amendment of standards of identity for enriched grain products to require the addition of folic acid. Federal Registry 61, 8781-8809.

Freyburger G, Labrouche S, Sassoust G, Rouanet F, Javorschi S \& Parrot F (1997) Mild hyperhomocysteinemia and hemostatic factors in patients with arterial vascular disease. Thrombosis and Haemostasis 77, 466-471.

Frosst P, Blom HJ, Milos R, Goyette P, Sheppard CA, Matthews RG, Boers GHJ, den Heijer M, Kluijtmans LAJ, van den Heuvel LP \& Rozen R (1995) A candidate genetic risk factor for vascular disease: a common mutation in methylenetetrahydrofolate reductase. Nature Genetics 10, 111-113.

Fryer RH, Wilson BD, Gubler DB, Fitzgerald LA \& Rodgers GM (1993) Homocysteine as a risk factor for premature vascular disease and thrombosis, induces tissue factor activity in endothelial cells. Atherosclerosis and Thrombosis 13, 1327-1333.

Garg UD \& Hassid A (1989) Nitric oxide-generating vasodilators and 8-bromo-cyclic guanosine monophosphate inhibit mitogenesis amd proliferation of cultured rat vascular smooth muscle cells. Journal of Clinical Investigation 93, 1774-1777.

Gerritsen T \& Waisman HA (1964) Homocystinuria, an error in the metabolism of methionine. Pediatrics 33, 413-420.

Goodman SI, Moe PG, Hammond KB, Mudd SH \& Uhlendorf BW (1970) Homocystinuria with methylmalonic aciduria: two cases of a sibship. Biochemical Medicine 4, 500-515.

Graeber JE, Slott JH, Ulane RE, Schulman JD \& Stuart MJ (1982) Effect of homocysteine and homocystine on platelet and vascular arachidonic acid metabolism. Pediatric Research 16, 490-493.

Graham IM, Daly LE, Refsum HM, Robinson K, Brattstrom LE, Ueland PM, Palma-Reis RJ \& Boers GHJ (1997) Plasma homocysteine as a risk factor for vascular disease: The European Concerted Action Project. Journal of the American Medical Association 277, 1775-1781.

Greenlund KJ, Srinivasan SR, Xu J-H, Dalferes E, Myers L, Pickoff A \& Berenson GS (1999) Plasma homocysteine distribution and its association with parental history of coronary artery disease in black and white children: The Bogalusa Heart Study. Circulation 99, 2144-2149.

Gudnason V, Stansbie D, Scott J, Bowron A, Nicaud V \& Humphries S (1998) C677T (thermolabile alanine/valine) polymorphism in methylenetetrahydrofolate reductase (MTHFR): its frequency and impact on plasma homocysteine concentration in different European populations. Atherosclerosis 136, 347-354.

Guenther BD, Sheppard CA, Tran P, Rozen R, Matthews RG \& Ludwig ML (1999) The structure and properties of methylenetetrahydrofolate reductase from Escherichia coli suggest how folate ameliorates human hyperhomocysteinemia. Nature Structural Biology 6, 359-365.

Gupta A, Moustapha A, Jacobsen DW, Goormastic M, Tuzcu EM, Hobbs R, Young J, James K, McCarthy P, van Lente F, Green R \& Robinson K (1998) High homocysteine, low folate, and low vitamin B6 concentration - prevalent risk factors for vascular disease in heart transplant recipients. Transplantation 65, $544-550$.

Guttormsen AB, Ueland PM, Nesthus I, Nygard O, Schneede J, Vollset SE \& Refsum H (1996) Determinants and vitamin responsiveness of intermediate hyperhomocysteinemia (> $40 \mu \mathrm{mol} / \mathrm{liter}$ ). The Hordaland Homocysteine Study. Journal of Clinical Investigation 98, 2174-2183.

Hajjar KA (1993) Homocysteine-induced modulation of tissue plasminogen activator binding to its endothelial cell membrane receptor. Journal of Clinical Investigation 91, 2873-2879.

Hajjar KA, Mauri L, Jacovina AT, Zhong F, Mirza VA, Padovan JC \& Chait BT (1998) Tissue plasminogen activator binding to the 
annexin II tail domain. Journal of Biological Chemistry 273, 9987-9993.

Hamfelt A \& Soderhjelm L (1988) Vitamin B-6 and aging. In Clinical and Physiological Applications of Vitamin B-6, pp. 95-107 (JE Leklem and RD Reynolds, editors]. New York: Alan R. Liss Inc.

Harker LA, Harlan JM \& Ross R (1983) Effect of sulfinpyrazone on homocysteine-induced endothelial injury and arteriosclerosis in baboons. Circulation Research 53, 731-739.

Harker LA, Ross R, Slichter SJ \& Scott CR (1976) Homocysteineinduced arteriosclerosis: The role of endothelial cell injury and platelet response in its genesis. Journal of Clinical Investigation 58, 731-741.

Harker LA, Slichter SJ, Scott CR \& Ross R (1974) Homocystinuria: Vascular injury and arterial thrombosis. New England Journal of Medicine 291, 537-543.

Harmon DL, Woodside JV, Yarnell JWG, McMaster D, Young IS, McCrum EE, Gey KF, Whitehead AS \& Evans AE (1996) The common 'thermolabile' variant of methylenetetrahydrofolate reductase is a major determinant of mild hyperhomocysteinaemia. Quarterly Journal of Medicine 89, 571-577.

Harpel PC, Chang VT \& Borth W (1992) Homocysteine and other sulfydryl compounds enhance the binding of lipoprotein (a) to fibrin: A potential biochemical link between thrombosis, atherogenesis, and sulfydryl compound metabolism. Proceedings of the National Academy of Sciences USA 89, 10193-10197.

Hayashi T, Honda G \& Suzuki K (1992) An atherogenic stimulus homocysteine inhibits cofactor activity of thrombomodulin and enhances thrombomodulin expression in human umbilical vein endothelial cells. Blood 79, 2930-2936.

Healy H, Booth C, Clague A \& Wesyhuyzen J (1998) Hyperhomocysteinaemia in end-stage renal failure patients: Effect of lowdose supplementation with folic acid. Nephrology 4, 413-418.

Heijmans BT, Gussekloo J, Kluft C, Droog S, Lagaay AM, Knook DL, Westendorp RGJ \& Slagboom EP (1999) Mortality risk in men is associated with a common mutation in the methylenetetrahydrofolate reductase gene (MTHFR). European Journal of Human Genetics 7, 197-204.

Heinecke JW, Rosen H, Suzuki LA \& Chait A (1987) The role of sulfur-containing amino acids in superoxide production and modification of low density lipoprotein by arterial smooth muscle cells. Journal of Biological Chemistry 262, 1009810103.

Hladovec J (1979) Experimental homocystinemia, endothelial lesions and thrombosis. Blood Vessels 16, 202-205.

Hoffman RM (1985) Altered methionine metabolism and transmethylation in cancer. Anticancer Research 5, 1-30.

Hopkins PN, Wu LL, Wu J, Hunt SC, James BC, Michael Vincent G \& Williams RR (1995) Higher plasma homocyst(e)ine and increased susceptibility to adverse effects of low folate in early familial coronary artery disease. Arteriosclerosis, Thrombosis and Vascular Biology 15, 1314-1320.

Israelsson B, Brattstrom LE \& Hultberg BL (1988) Homocysteine and myocardial infarction. Atherosclerosis 71, 227-233.

Jacobsen DW (1998) Acquired hyperhomocysteinemia in heart transplant recipients. Clinical Chemistry 44, 2238-2239.

Jacques PF, Bostom AG, Williams RR, Ellison RC, Eckfeldt JH, Rosenberg IH, Selhub J \& Rozen R (1996) Relation between folate status, a common mutation in methylenetetrahydrofolate reductase and plasma homocysteine concentrations Circulation 93, 7-9.

Jacques PF, Selhub J, Bostom AG, Wilson PWF \& Rosenberg IH (1999) The effect of folic acid fortification on plasma folate and total homocysteine concentrations. New England Journal of Medicine 340, 1449-1454.

Jakubowski H (1997) Metabolism of homocysteine thiolactone in human cell cultures: Possible mechanism for pathological consequences of elevated homocysteine levels. Journal of Biological Chemistry 272, 1935-1942.

Kang S-S, Wong PWK, Cook HM, Norusis M \& Messer JV (1986a) Protein-bound homocyst(e)ine: A possible risk factor for coronary artery disease. Journal of Clinical Investigation 77, $1482-1486$

Kang S-S, Wong PWK \& Curley K (1982) The effect of D-penicillamine on protein-bound homocyst(e)ine in homocystinurics. Pediatric Research 16, 370-372.

Kang S-S, Wong PWK, Glickman PB, MacLeod CM \& Jaffe IA (1986b) Protein-bound homocyst(e)ine in patients with rheumatoid arthritis undergoing D-penicillamine treatment. Journal of Clinical Pharmacology 26, 712-715.

Kang S-S, Wong PWK \& Malinow MR (1992) Hyperhomocyst(e)inemia as a risk factor for occlusive vascular disease. Annual Review of Nutrition 12, 279-298.

Kang S-S, Wong PWK \& Norusis M (1987) Homocysteinemia due to folate deficiency. Metabolism 36, 458-462.

Kark JD, Selhub J, Adler B, Gofin J, Abramson JH, Friedman G \& Rosenberg IH (1999) Nonfasting plasma total homocysteine level and mortality in middle-aged and elderly men and women in Jerusalem. Annals of Internal Medicine 131, 321-330.

Keaney JF \& Loscalzo J (1997) Homocyst(e)ine decreases bioavailable nitric oxide by a mechanism involving glutathione peroxidase. Journal of Biological Chemistry 272, 17012-17017.

Koehler KM, Romero LJ, Stauber PM, Parreo-Tubbeh SL, Liang HC, Baumgartner RN, Garry PJ, Allen RH \& Stabler SP (1996) Vitamin supplementation and other variables affecting serum homocysteine and methylmalonic acid concentration in elderly men and women. Journal of the American College of Nutrition 15, 364-376.

Konecki E \& Feinberg H (1980) Pyridoxal phosphate inhibition of platelet function. American Journal of Physiology 238, H54-H60.

Konecky N, Malinow MR, Tunick PA, Freedberg RS, Rosenzweig BP, Katz ES, Hess DL, Upson B, Leung B, Perez J \& Kronson I (1997) Correlation between plasma homocyst(e)ine and aortic atherosclerosis. American Heart Journal 133, 534-540.

Kokame K, Kato H \& Miyata T (1996) Homocysteine-respondent genes in vascular endothelial cells identified by differential display analysis. Journal of Biological Chemistry 271, 29659-29665.

Kraus JP (1998) Biochemistry and molecular genetics of cystathionine $\beta$-synthase deficiency. European Journal of Pediatrics 157, Suppl. 2, S50-S53.

Lakshmi AV \& Ramalakshmi BA (1998) Effect of pyridoxine or riboflavin supplementation on plasma homocysteine levels in women with oral lesions. National Medical Journal of India 11, $171-172$.

Lam SC, Harfenist EJ, Packham MA \& Mustard JF (1980) Investigation of possible mechanisms of pyridoxal $5^{\prime}$-phosphate inhibition of platelet reactions. Thrombosis Research 20, 633-645.

Landgren F, Israelsson B, Lindgren A, Hultberg B, Andersson A \& Brattstrom L (1995) Plasma homocysteine in acute myocardial infarction: homocysteine-lowering effect of folic acid. Journal of Internal Medicine 237, 381-388.

Lentz SR \& Sadler JE (1991) Inhibition of thrombomodulin surface expression and protein $\mathrm{C}$ activation by the thrombogenic agent homocysteine. Journal of Clinical Investigation 88, 1906-1914.

Lentz SR \& Sadler JE (1993) Homocysteine inhibits von Willebrand factor processing and secretion by preventing transport from the endoplasmic reticulum. Blood 81, 683-689.

Lentz SR, Sobey CG, Piegors DJ, Bhopatkar MY, Faraci FM, Malinow MR \& Helstad DD (1996) Vascular dysfunction in monkeys with diet-induced hyperhomocyst(e)inemia. Journal of Clinical Investigation 98, 24-29. 
Levy HL, Mudd SH, Schulman JD, Dreyfus PM \& Abeles RH (1970) A derangement in B12 metabolism associated with homocystinemia, cystathioninemia, hypomethioninemia and methylmalonic aciduria. American Journal of Medicine 48, 390-397.

Liao JK, Shin WS, Lee WY \& Clark SL (1995) Oxidised lowdensity lipoprotein decreases the expression of endothelial nitric oxide synthase. Journal of Biological Chemistry 270, 319-324.

Lindgren A, Brattstrom L, Norrving B, Hultberg B, Andersson A \& Johansson BB (1995) Plasma homocysteine in the acute and convalescent phases after stroke. Stroke 26, 795-800.

Loscalzo J (1996) The oxidant stress of hyperhomocyst(e)inemia. Journal of Clinical Investigation 98, 5-7.

Lubec B, Ladudova O, Hoeger H, Muetil A, Fang-Kircher S, Marx M, Mosgoeller W \& Gialamac J (1996) Homocysteine increases cyclin-dependent kinase in aortic rat tissue. Circulation 94, $2620-2625$.

McCaddon A, Davies G \& Hudson P (1998) Total serum homocysteine in senile dementia of the Alzheimers type. International Journal of Geriatric Psychiatry 13, 235-239.

McCormick DB (1989) Two interconnected B vitamins: riboflavin and pyridoxine. Physiology Reviews 69, 1170-1198.

McCully KS (1969) Vascular pathology of homocysteinemia: Implications for the pathogenesis of arteriosclerosis. American Journal of Pathology 56, 111-128.

Ma J, Stampfer MJ, Hennekens CH, Frosst P, Selhub J, Horsford J, Malinow MR, Willett WC \& Rozen R (1996) Methylenetetrahydrofolate reductase polymorphism, plasma folate, homocysteine, and risk of myocardial infarction in US physicians. Circulation 94, 2410-2416.

Malinow MR, Ducimetiere P, Luc G, Evans AE, Arveiler D, Cambien F \& Upson BM (1996) Plasma homocyst(e)ine levels and graded risk for myocardial infarction: findings in two populations at contrasting risk for coronary heart disease. Atherosclerosis 126, 27-34.

Malinow MR, Kang SS, Taylor LM, Wong PWK, Coull B, Inahara T, Mukerjee D, Sexton G \& Upson B (1989) Prevalence of hyperhomocyst(e)inemia in patients with peripheral arterial occlusive disease. Circulation 79, 1180-1188.

Malinow MR, Nieto FJ, Szklo M, Chambless LE \& Bond G (1993) Carotid artery intimal-medial wall thickening and plasma homocyst(e)ine in asymptomatic adults. Circulation 87, 1107-1113.

Mansoor MA, Bergmark C, Svardal AM, Lonning PE \& Ueland PM (1995) Redox status and protein binding of plasma homocysteine and other aminothiols in patients with early-onset peripheral vascular disease. Arteriosclerosis, Thrombosis and Vascular Biology 15, 232-240.

Mansoor MA, Kristensen O, Hervig T, Bates CJ, Pentieva K, Vefring H, Osland A, Berge T, Drablos PA, Hetland O \& Rolfsen S (1999) Plasma total homocysteine response to oral doses of folic acid and pyridoxine hydrochloride (vitamin B6) in healthy individuals. Oral doses of vitamin B6 reduce concentrations of serum folate. Scandinavian Journal of Clinical Laboratory Investigation 59, 139-146.

Marks DSJA, Vita JD, Folts JF, Keaney GN Jr \& Loscalzo J (1995) Inhibition of neoitimal proliferation in rabbits following vascular injury by a single treatment with a protein adduct of nitric oxide. Journal of Clinical Investigation 96, 141-149.

Markus HS, Nadira A, Swaminathan R, Sankaralingham A, Molloy J \& Powell J (1997) A common polymorphism in the methylenetetrahydrofolate reductase gene, homocysteine, and ischaemic cerebrovascular disease. Stroke 28, 1739-1743.

Massy ZA, Chadefaux-Vekemans B, Chevalier A, Bader CA, Drueke TB, Legendre C, Lacour B, Kamoun P \& Kreis H (1994) Hyperhomocysteinaemia: a significant risk factor for cardio- vascular disease in renal transplant recipients. Nephrology Dialysis Transplantation 9, 1103-1108.

Massy ZA, Mamzer-Bruneel M-F, Chevalier A, Millet P, Helenon O, Chadefaux-Vekemans B, Legendre C, Bader C, Drueke T, Lacour B \& Kreis H (1998) Carotid atherosclerosis in renal transplant recipients. Nephrology Dialysis Transplantation 13, 1792-1798.

Miller JW (1999) Homocysteine and Alzheimer's disease. Nutrition Reviews 57, 126-129.

Miller JW, Nadeau MR, Smith D \& Selhub J (1992) Folate deficiency Vs vitamin B6 deficiency: comparison of responses to methionine loading. American Journal of Clinical Nutrition 59, 1033-1039.

Molloy AM, Daly S, Mills JL, Kirke PN, Whitehead AS, Ramsbottom D, Conley MR, Weir DG \& Scott JS (1997) Thermolabile variant of 5,10-methylenetetrahydrofolate reductase associated with low red-cell folates: implications for folate intake recommendations. Lancet 349, 1591-1593.

Montalescot G, Ankri A, Chadefaux-Vekemans B, Balcher J, Philippe F, Drobinski G, Benzidia R, Kamoun P \& Thomas D (1997) Plasma homocysteine and the extent of atherosclerosis in patients with coronary artery disease. International Journal of Cardiology 60, 295-300.

Morgan SL, Baggott JE, Lee JY \& Alarcon GS (1998) Folic acid supplementation prevents deficient blood folate levels and hyperhomocysteinemia during longterm, low dose methotrexate therapy for Rheumatoid Arthritis: Implications for cardiovascular disease prevention. Journal of Rheumatology 25, 441-446.

Motulsky AG (1996) Nutritional ecogenetics: Homocysteinerelated arteriosclerotic vascular disease, neural tube defects, and folic acid. American Journal of Human Genetics 58, 17-20.

Moustapha A, Naso A, Nahlawi M, Gupta A, Arheart KL, Jacobsen DW, Robinson K \& Dennis VW (1998) Prospective study of hyperhomocysteinemia as an adverse cardiovascular risk factor in end-stage renal disease. Circulation 97, 138-141.

Mudd SH, Finkelstein JD, Irreverre F \& Laster L (1964) Homocystinuria: An enzymatic defect. Science 143, 1443-1445.

Mudd SH, Levy HL \& Skovby F (1995) Disorders of transsulfuration. In The Metabolic Basis of Inherited Disease, 7th ed., pp. 1279-1327 [CR Scriver, AL Beaudet, WS Sly and D Valle, editors]. New York: McGraw-Hill.

Mudd SH, Skovby F, Levy HL, Pettigrew KD, Wilcken B, Pyeritz RE, Boers AGHJ, Bromberg IL, Cerone R, Fowler B, Grobe H \& Schimdt H (1985) The natural history of homocystinuria due to cystathionine B-synthase deficiency. American Journal of Human Genetics 37, 1-31.

Murray JC, Frazer DR \& Levene CI (1978) The effect of pyridoxine deficiency on lysyl oxidase activity in the chick. Experiments in Molecular Pathology 28, 301-308.

Myers BA, Dubick MA, Reynolds RD \& Rucker RB (1985) Effect of vitamin B-6 (pyridoxine) deficiency on lung elastin crosslinking in perinatal and weanling rat pups. Biochemical Journal 229, 153-160.

Naruszewicz M, Mirkiewicz E \& Olszewski AJ (1994) Lowdensity lipoprotein by homocysteine thiolactone causes increased aggregation and altered interaction with cultured macrophages. Nutrition Metabolism and Cardiovascular Disease 4, 70-77.

Naughton ER, Yap S \& Mayne PD (1998) Newborn screening for homocystinuria: Irish and world experience. European Journal of Pediatrics 157, Suppl. 2, S84-S87.

Nishinaga M, Ozawa T \& Shimada K (1993) Homocysteine, a thrombogenic agent, suppresses anticoagulant heparan sulfate expression in cultured porcine aortic endothelial cells. Journal of Clinical Investigation 92, 1381-1386. 
Nygard O, Nordrehaug JE, Refsum H, Ueland PM, Farstad M \& Vollset SE (1997a) Plasma homocysteine levels and mortality in patients with Coronary Heart Disease. New England Journal of Medicine 337, 230-236.

Nygard O, Refsum H, Ueland PM, Stensvold I, Nordrehaug JE, Kvale G \& Vollset SE (1997b) Coffee consumption and plasma total homocysteine: The Hordaland Homocysteine Study. American Journal of Clinical Nutrition 65, 136-143.

Nygard O, Refsum H, Ueland PM \& Vollset SE (1998) Major lifestyle determinants of plasma total homocysteine distribution: The Hordaland Homocysteine Study. American Journal of Clinical Nutrition 67, 263-270.

Nygard O, Vollset SE, Refsum H, Stensvold I, Tverdal A, Nordehaug JE, Ueland PM \& Kuale G (1995) Total plasma homocysteine and cardiovascular risk profile: The Hordaland Homocysteine Study. Journal of the American Medical Association 274, 1526-1533.

Olszewski AJ, Szostak WB, Bialkowska M, Rudnicki S \& McCully KS (1989) Reduction of plasma lipid and homocysteine levels by pyridoxine, folate, cobalamin, choline, riboflavin, and troxerutin in atherosclerosis. Atherosclerosis 75, 1-6.

Osganian SK, Stampfer MJ, Spiegelman D, Rimm E, Cutler JA, Feldman HA, Montgomery DH, Webber LS, Lytle LA, Bausserman L \& Nader PR (1999) Distribution of and factors associated with serum homocysteine levels in children. Journal of the American Medical Association 281, 1189-1196.

Outinen PA, Sood SK, Liaw PCY, Seage KD, Maeda N, Hirsh J, Ribau J, Podor TJ, Weitz JI \& Austin RC (1998) Characterisation of the stress-inducing effects of homocysteine. Biochemistry Journal 332, 213-221.

Perry IH, Refsum H, Morris RW, Ebrahim SB, Ueland PM \& Shaper AG (1995) Prospective study of serum total homocysteine concentration and risk of stroke in middle-aged British men. Lancet 346, 1395-1398.

Petri M, Roubenoff R, Dallal GE, Nadeau MR, Selhub J \& Rosenberg IH (1996) Plasma homocysteine as a risk factor for atherothrombotic events in systemic lupus erythematosus. Lancet 348, 1120-1124.

Quinn CT, Griener JC, Bottiglieri T \& Kamen BA (1998) Methotrexate, homocysteine and seizures. Journal of Clinical Oncology 16, 393-394.

Rasmussen K, Moller J, Lyngbak M, Pedersen HA \& Dybkjer L (1996) Age- and gender-specific reference intervals for total homocysteine and methylmalonic acid in plasma before and after vitamin supplementation. Clinical Chemistry 42, 630-636.

Ratnoff OD (1968) Activation of Hageman factor by L-homocysteine. Science 162, 1007-1009.

Reddy MN (1997) Reference ranges for total homocysteine in children. Clinica Chimica Acta 262, 153-155.

Refsum H, Guttormsen AB, Fiskerstrand T \& Ueland PM (1998a) Hyperhomocysteinemia in terms of steady-state kinetics. European Journal of Pediatrics 157, Suppl. 2, S45-S49.

Refsum H, Helland S \& Ueland PM (1989) Fasting plasma homocysteine as a sensitive parameter of antifolate effect: A study of psoriasis patients receiving low-dose methotrexate treatment. Clinical Pharmacological Therapy 46, 510-520.

Refsum H \& Ueland PM (1990) Clinical significance of pharmacological modulation of homocysteine metabolism. Trends in Pharmacological Science 11, 411-416.

Refsum H, Ueland PM \& Kvinsland S (1986) Acute and long-term effects of high-dose methotrexate treatment on homocysteine in plasma and urine. Cancer Research 46, 5385-5391.

Refsum H, Ueland PM, Nygard O \& Vollset SE (1998b) Homocysteine and cardiovascular disease. Annual Review of Medicine 49, 31-62.

Refsum H, Wesenberg F \& Ueland PM (1991) Plasma homocysteine in children with acute lymphoblastic leukemia: Changes during a chemotherapeutic regimen including methotrexate. Cancer Research 51, 828-835.

Reynolds RD, Mosser-Veillon PB \& Kant AK (1988) Effect of age on status and metabolism of Vitamin B-6 in men. In Clinical and Physiological Applications of Vitamin B-6, pp. 109-125 [JE Leklem and RD Reynolds, editors]. New York: Alan R. Liss Inc.

Ridker PM, Hennekens CH, Selhub J, Miletich JP, Malinow MR \& Stampfer MJ (1997) Interrelation of hyperhomocyst(e)inemia, factor V leiden, and risk of future venous thromboembolism. Circulation 95, 1777-1782.

Ridker PM, Manson JE, Buring JE, Shih J, Martias M \& Hennekens $\mathrm{CH}$ (1999) Homocysteine and risk of cardiovascular disease among postmenopausal women. Journal of the American Medical Association 281, 1817-1821.

Riggs KM, Spiro A, Tucker K \& Rush D (1996) Relations of vitamin B-12, vitamin B-6, folate, and homocysteine to cognitive performance in the Normative Aging Study. American Journal of Clinical Nutrition 63, 306-314.

Rimm EB, Willett WC, Hu FB, Sampson L, Colditz GA, Manson JE, Hennekens C \& Stampfer MJ (1998) Folate and vitamin B6 from diet and supplements in relation to risk of coronary heart disease among women. Journal of the American Medical Association 279, 359-364.

Rinehart JF \& Greenberg LD (1949) Arteriosclerotic lesions in pyridoxine-deficient monkeys. American Journal of Pathology 25, 481-491.

Robinson K, Arheart K, Refsum H, Brattstrom L, Boers G, Ueland P, Rubba P, Palma-Reis R, Meleady R, Daly L, Witteman J \& Graham I (1998) Low circulating folate and vitamin B6 concentrations - Risk factors for stroke, peripheral vascular disease, and coronary artery disease. Circulation 97, 437-443.

Robinson K, Mayer EL, Miller DP, Green R, van Lente F, Gupta A, Kottre-Marchant K, Savon SR, Selhub J, Nissen SE, Kutner M, Topol EJ \& Jacobsen DW (1995) Hyperhomocysteinemia and low pyridoxal phosphate: common and independent reversible risk factors for coronary artery disease. Circulation 92, 28252830.

Rodgers GM \& Conn MT (1990) Homocysteine, an atherogenic stimulus, reduces protein $\mathrm{C}$ activation by arterial and venous endothelial cells. Blood 75, 895-901.

Rodgers GM, Fryer RH, Wilson BD, Gubler DB \& Fitxgerald LA (1993) Homocysteine, a risk factor for vascular disease and thrombosis, induces tissue factor activity in endothelial cells. Clinical Research 41, 19A.

Rodgers GM \& Kane WH (1986) Activation of endogenous Factor $\mathrm{V}$ by a homocysteine-induced vascular endothelial cell activator. Journal of Clinical Investigation 77, 1909-1916.

Rosenberg IH \& Rosenberg LE (1998) The implications of genetic diversity for nutrient requirements: The case of folate. Nutrition Reviews 56, S47-S53.

Rosenblatt DS (1995) Inherited disorders of folate transport and metabolism. In The Metabolic Basis of Inherited Disease, 7th ed., pp. 3111-3128 [CR Scriver, AL Beaudet, WS Sly and D Valle, editors]. New York: McGraw-Hill.

Savage DG \& Lindenbaum J (1995) Folate-cobalamin interactions. In Folate in Health and Disease, pp. 329-360 [LB Bailey, editor]. New York: Marcel Dekker.

Schroeder HA (1955) Is atherosclerosis a conditioned pyridoxal deficiency? Journal of Chronic Disease 2, 28-41.

Schwaninger M, Ringleb P, Winter R, Kohl B, Fiehn W, Rieser PA \& Sack WI (1999) Elevated plasma concentrations of homocysteine in antiepileptic drug treatment. Epilepsia 40, 345-350.

Selhub J, Jacques PF, Bostom AG, D'Agostino RB, Wilson PWF, Belanger AJ, O'Leary DH, Wolf PA, Schaefer EJ \& Rosenberg IH (1995) Association between plasma homocysteine concentration and extracranial carotid-artery stenosis. New England Journal of Medicine 332, 286-291. 
Selhub J, Jacques PF, Wilson PWF, Rush D \& Rosenberg IH (1993) Vitamin status and intake as primary determinants of homocysteinemia in an elderly population. Journal of the American Medical Association 270, 2693-2698.

Selhub J \& Miller J (1992) The pathogenesis of homocysteinemia: interruption of the coordinate regulation by S-adenosylmethionine of the remethylation and transsulfuration of homocysteine. American Journal of Clinical Nutrition 55, 131-138.

Shemin D, Lapane KL, Bausserman L, Kanaan E, Kahn S, Dworkin L \& Bostom AG (1999) Plasma total homocysteine and hemodialysis access thrombosis: A prospective study. Journal of the American Society of Nephrology 10, 1095-1099.

Shimakawa T, Nieto FJ, Malinow MR, Chambless LE, Schreiner PJ \& Szklo M (1997) Vitamin intake: A possible determinant of plasma homocyst(e)ine among middle-aged adults. Annals of Epidemiology 7, 285-293.

Shultz TD \& Hansen CM (1998) Plasma homocysteine concentrations change with vitamin B-6 depletion and repletion in young women. Nutrition Research 18, 975-978.

Simioni P, Prandoni P, Burlina A, Tormene D, Sardella C, Ferrari V, Benedetti L \& Girolami A (1996) Hyperhomocysteinemia and deep-vein thrombosis: A case-control study. Thrombosis and Haemostasis 76, 883-886.

Sirrs S, Duncan L, Djurdjev O, Nussbaumer G, Ganz G, Frohlich J \& Levin A (1999) Homocyst(e)ine and vascular access complications in haemodialysis patients: insights into a complex metabolic relationship. Nephrology Dialysis Transplantation 14, 738-743.

Slavik M, Hyanek J, Ellis J \& Homolka J (1969) Typical hyperaminoaciduria after high doses of 6-azauridine triacetate. Biochemical Pharmacology 18, 1782-1784.

Slavik M, Smith KJ \& Blanco O (1982) Decrease of serum pyridoxal phosphate level and homocystinemia after administration of 6-azauridine triacetate and their prevention by administration of pyridoxine. Biochemical Pharmacology 31, 4089-4092.

Smolin LA, Crenshaw TD, Kurtycz D \& Benevenga NJ (1983) Homocyst(e)ine accumulation in pigs fed diets deficient in vitamin B6: relationship to atherosclerosis. Journal of Nutrition 113, 2122-2133.

Stabler SP, Sampson DA, Waing L-P \& Allen RH (1997) Elevations of serum cystathionine and total homocysteine in pyridoxine-, folate-, and cobalamin-deficient rats. Nutritional Biochemistry 8, 279-289.

Stamler JS, Osborne JA, Jaraki O, Rabbani LE, Mullins M, Singel D \& Loscalzo J (1993) Adverse effects of homocysteine are modulated by endothelium-derived relaxing factor and oxides of nitrogen. Journal of Clinical Investigation 91, 308-318.

Stampfer MJ, Malinow MR, Willett WC, Mewcomer LM, Upson B, Ullmann D, Tishler PV \& Hennekens CH (1992) A prospective study of plasma homocyst(e)ine and risk of myocardial infarction in US physicians. Journal of the American Medical Association 268, 877-881.

Starkebaum G \& Harlan JM (1986) Endothelial cell injury due to copper-catalysed hydrogen peroxide generation from homocysteine. Journal of Clinical Investigation 77, 1370-1376.

Stehouwer CD, Weijenberg MP, van den Berg M, Jakobs C, Feskens EJM \& Kromhout D (1998) Serum homocysteine and risk of coronary heart disease and cerebrovascular disease in elderly men. A 10-year follow-up. Arteriosclerosis, Thrombosis and Vascular Biology 18, 1895-1901.

Stolzenberg-Solomon RZ, Miller ER, Maguire MG, Selhub J \& Appel LJ (1999) Association of dietary protein intake and coffee consumption with serum homocysteine concentrations in an older population. American Journal of Clinical Nutrition 69. $467-475$.
Subbarao K, Kuchibhotla J \& Kakkar VV (1979) Pyridoxal 5'-phosphate - A new physiological inhibitor of blood coagulation and platelet function. Biochemical Pharmacology 28, 531-534.

Tawakol A, Omland T, Gerhard M, Wu JT \& Creager MA (1997) Hyperhomocyst(e)inemia is associated with impaired endothelium-dependent vasodilation in humans. Circulation 95, $1119-1121$.

Taylor LM, DeFrang RD, Harris EJ \& Porter JM (1991) The association of elevated plasma homocyst(e)ine with progression of symptomatic peripheral arterial disease. Journal of Vascular Surgery 13, 128-136.

Taylor LM, Moneta GL, Sexton GJ, Schuff RA, Porter JM \& The Homocysteine and Progression of Atherosclerosis Study Investigators (1999) Prospective blinded study of the relationship between plasma homocysteine and progression of symptomatic peripheral arterial disease. Journal of Vascular Surgery 29, 8-21.

Tonstad S, Joakimsen O, Stenstad-Bugge E, Leren TP, Ose L, Russell D \& Bonaa KH (1996a) Risk factors related to carotid intima-media thickness and plaque in children with familial hypercholesterolemia and control subjects. Arteriosclerosis, Thrombosis and Vascular Biology 16, 984-991.

Tonstad S, Refsum H, Siversten M, Christpherson B, Ose L \& Ueland PM (1996b) Relation of total homocysteine and lipid levels in children to premature cardiovascular death in male relatives. Pediatric Research 40, 47-52.

Tonstad S, Refsum H \& Ueland PM (1997) Association between plasma total homocysteine and parental history of cardiovascular disease in children with familial hypercholesterolemia. Circulation 96, 1803-1808.

Tsai J-C, Perrella MA, Yoshizumi M, Hseith C-M, Haber E, Schlegel R \& Lee M-E (1994) Promotion of vascular smooth muscle cell growth by homocysteine: A link to atherosclerosis. Proceedings of the National Academy of Sciences USA 91, 6369-6373.

Tsai JC, Wang H, Perella MA, Yoshizumi M, Sibinga NES, Tan LC, Haber E, Chang THT, Schlegel R \& Lee ME (1996) Induction of cyclin A gene expression by homocysteine in vascular smooth muscle cells. Journal of Clinical Investigation 97, 146-153.

Ubbink JB, Becker PJ, Vermaak WJH \& Delport R (1995) Results of B-vitamin supplementation study used in a prediction model to define a reference range for plasma homocysteine. Clinical Chemistry 41, 1033-1037.

Ubbink JB, Delport R \& Vermaak WJH (1996) Plasma homocysteine concentrations in a population with a low coronary heart disease prevalence. Journal of Nutrition 126, 1254S-1257S.

Ubbink JB, Vermaak WJH, van der Merwe A, Becker PJ, Delport R \& Potgieter HC (1994) Vitamin requirements for the treatment of hyperhomocysteinemia in humans. Journal of Nutrition 124, 1927-1933.

Ueland PM \& Refsum H (1989) Plasma homocysteine, a risk factor for vascular disease: Plasma levels in health, disease, and drug therapy. Journal of Laboratory and Clinical Medicine 114, 473501.

Ueland PM, Refsum H, Stabler SP, Malinow R, Andersson A \& Allen RH (1993) Total homocysteine in plasma or serum: Methods and clinical applications. Clinical Chemistry 39, 1764-1779.

Upchurch GR Jr, Welch GN, Freedman JE \& Loscalzo J (1995) Homocysteine attenuates endothelial glutathione peroxidase and thereby potentiates peroxide-mediated cell injury. Circulation 92, 1086.

Upchurch GR, Welch GN, Fabian AJ, Freedman JE, Johnson JL, Keaney JF \& Loscalzo J (1997) Homocyst(e)ine decreases 
bioavailable nitric oxide by a mechanism involving glutathione peroxidase. Journal of Biological Chemistry 272, 17012-17017. Upchurch GR, Welch GN \& Loscalzo J (1996) Homocysteine, EDRF and endothelial function. Journal of Nutrition 126, 1290S-1294S.

van den Berg M, Boers GH, Franken DG, Blom HJ, van Kamp GJ, Jakobs C, Rauwerda JA, Kluft C \& Stehouwert CD (1995) Hyperhomocysteinaemia and endothelial dysfunction in young patients with peripheral arterial occlusive disease. European Journal of Clinical Investigation 25, 176-181.

van den Berg M, Stehouwer CD, Bierdrager E \& Rauwerda JA (1996) Plasma homocysteine and severity of atherosclerosis in young adults with lower-limb atherosclerotic disease. Arteriosclerosis, Thrombosis and Vascular Biology 16, 165-171. van der Mooren MJ, Wouters MGAJ, Blom HJ, Schellekens LA, Eskes TKAB \& Rolland R (1994) Hormone replacement therapy may reduce high serum homocysteine in postmenopausal women. European Journal of Clinical Investigation 24, 357-360.

van Guldener C, Janssen MJFM, Lambert J, Wee PM, Donker AJM \& Stehouwer CDA (1998) Folic acid treatment of hyperhomocysteinemia in peritoneal dialysis patients: No change in endothelial function after long-term therapy. Peritoneal Dialysis International 18, 282-289.

van Guldener C, Kulik W, Berger R, Dijkstra DA, Jakobs C, Reijngoud DJ, Donker AJM, Stehouwer CDA \& de Meer K (1999) Homocysteine and methionine metabolism in ESRD: A stable isotope study. Kidney International 56, 1064-1071.

Velury S \& Howell SB (1988) Measurement of plasma thiols after derivitisation with monobromobimane. Journal of Chromatography 424, 141-146.

Verhoef P, Hennekens CH, Allen RH, Stabler SP, Willett WC \& Stampfer MJ (1997a) Plasma total homocysteine and risk of angina pectoris with subsequent coronary artery bypass surgery. American Journal of Cardiology 79, 799-801.

Verhoef P, Hennekens CH, Malinow MR, Kok FJ, Willett WC \& Stampfer MJ (1994) A prospective study of plasma homocyst(e)ine and risk of ischemic stroke. Stroke 25, 1924-1930.

Verhoef P, Kok FJ, Kruyssen DACM, Schouten EG, Witteman JCM, Grobbee DE, Ueland PM \& Refsum H (1997b) Plasma total homocysteine, B vitamins, and risk of coronary atherosclerosis. Arteriosclerosis, Thrombosis and Vascular Biology 17, 989-995.

Verhoef P, Meleady R, Daly LE, Graham IM, Robinson K \& Boers GHJ (1999) Homocysteine, vitamin status and risk of vascular disease - Effects of gender and menopausal status. European Heart Journal 20, 1234-1244.

Verhoef P, Stampfer MJ, Buring JE, Gaziano JM, Allen RH, Stabler SP, Reynolds RD, Kok FJ, Hennekens CH \& Willett WC (1996) Homocysteine metabolism and risk of myocardial- infarction - Relation with vitamin-B6, vitamin-B12, and folate. American Journal of Epidemiology 143, 845-859.

Vilaseca MA, Moyano D, Ferrer I \& Artuch R (1997) Total homocysteine in pediatric patients. Clinical Chemistry 43, 690-692.

Voutilainen S, Alfthan G, Nyssonen K, Salonen R \& Salonen JT (1998) Association between elevated plasma total homocysteine and increased common carotid artery wall thickness. Annals of Medicine 30, 300-306.

Wald NJ, Watt HC, Law MR, Weir DG, McPartlin J \& Scott JM (1998) Homocysteine and ischemic heart disease: Results of a prospective study with implications regarding prevention. Archives of Internal Medicine 158, 862-867.

Wall RT, Harlan JM, Harker LA \& Striker GE (1980) Homocysteine-induced endothelial cell injury in vitro: A model for the study of vascular injury. Thrombosis Research 18, $113-121$.

Wang J, Dudman NPB \& Wilcken DEL (1993) Effects of homocysteine and related compounds on prostacyclin production by cultured human vascular endothelial cells. Thrombosis and Haemostasis 70, 1047-1052.

Ward M, McNulty H, McPartlin J, Strain JJ, Weir DG \& Scott JM (1997) Plasma homocysteine, a risk factor for cardiovascular disease can be effectively lowered by physiological amounts of folic acid. Quarterly Journal of Medicine 90, 519-524.

Welch GN, Upchurch G \& Loscalzo J (1997) Hyperhomocyst(e)inemia and atherothrombosis. Annals of the New York Academy of Sciences 811, 48-59.

Wiklund O, Fager G, Andersson A, Lundstan U, Masson P \& Hultberg B (1996) N-acetylcysteine treatment lowers plasma homocysteine but not serum lipoprotein (a) levels. Atherosclerosis 119, 99-106.

Wilcken DEL, Gupta VJ \& Betts AK (1981) Homocysteine in the plasma of renal transplant recipients: effects of cofactors for methionine metabolism. Clinical Science 61, 743-749.

Wouters MG, Moorrees MT, van der Mooren MJ, Blom HJ, Boers GHJ, Schellekens LA, Thomas CMG \& Eskes TKAB (1995) Plasma homocysteine and menopausal status. European Journal of Clinical Investigation 25, 801-805.

Wu LL, Wu J, Hunt SC, James BC, Vincent GM, Williams RR \& Hopkins PN (1994) Plasma homocyst(e)ine as a risk factor for early familial coronary artery disease. Clinical Chemistry 40, $552-561$.

Yoo J-H, Park J-E, Hong K-P, Lee S-H, Kim D-K, Lee W-R \& Park S-C (1999) Moderate hyperhomocyst(e)inemia is associated with the presence of coronary artery disease and the severity of coronary atherosclerosis in Koreans. Thrombosis Research 94, $45-52$.

Young PB, Kennedy S, Molloy AM, Scott JM, Weir DG \& Kennedy DG (1997) Lipid peroxidation induced in vivo by hyperhomocysteinaemia in pigs. Atherosclerosis 129, 67-71. 